\title{
DNA End Joining: G0-ing to the Core
}

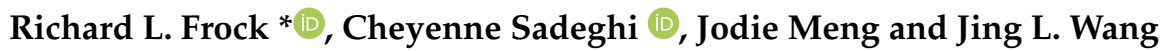

\begin{abstract}
Division of Radiation and Cancer Biology, Department of Radiation Oncology, Stanford University School of Medicine, Stanford, CA 94305, USA; csadeghi@stanford.edu (C.S.); jodieme@stanford.edu (J.M.); jlwang90@stanford.edu (J.L.W.)

* Correspondence: frock@stanford.edu
\end{abstract}

check for updates

Citation: Frock, R.L.; Sadeghi, C.; Meng, J.; Wang, J.L. DNA End Joining: G0-ing to the Core. Biomolecules 2021, 11, 1487. https:// doi.org/10.3390/biom11101487

Academic Editor: Valentyn Oksenych

Received: 17 September 2021

Accepted: 6 October 2021

Published: 9 October 2021

Publisher's Note: MDPI stays neutral with regard to jurisdictional claims in published maps and institutional affiliations.

Copyright: (c) 2021 by the authors. Licensee MDPI, Basel, Switzerland. This article is an open access article distributed under the terms and conditions of the Creative Commons Attribution (CC BY) license (https:/ / creativecommons.org/licenses/by/ $4.0 /)$.

\begin{abstract}
Humans have evolved a series of DNA double-strand break (DSB) repair pathways to efficiently and accurately rejoin nascently formed pairs of double-stranded DNA ends (DSEs). In G0/G1-phase cells, non-homologous end joining (NHEJ) and alternative end joining (A-EJ) operate to support covalent rejoining of DSEs. While NHEJ is predominantly utilized and collaborates extensively with the DNA damage response (DDR) to support pairing of DSEs, much less is known about A-EJ collaboration with DDR factors when NHEJ is absent. Non-cycling lymphocyte progenitor cells use NHEJ to complete V(D)J recombination of antigen receptor genes, initiated by the RAG1/2 endonuclease which holds its pair of targeted DSBs in a synapse until each specified pair of DSEs is handed off to the NHEJ DSB sensor complex, $\mathrm{Ku}$. Similar to designer endonuclease DSBs, the absence of $\mathrm{Ku}$ allows for A-EJ to access RAG1/2 DSEs but with random pairing to complete their repair. Here, we describe recent insights into the major phases of DSB end joining, with an emphasis on synapsis and tethering mechanisms, and bring together new and old concepts of NHEJ vs. A-EJ and on RAG2-mediated repair pathway choice.
\end{abstract}

Keywords: NHEJ; A-EJ; DSB repair; non-cycling; end joining; synapse; tethering; V(D)J recombination; translocation; functional redundancy

\section{Introduction}

Cells are tasked with constant surveillance and maintenance of genome integrity by various sources of DNA-damaging agents [1-4] that generate DNA lesions, expose DNA strands, and form double-stranded DNA ends (DSEs) [5-7] that are typically the result of a double-strand DNA break (DSB). Thus, multiple and simultaneous DSBs represent the greatest risk for catastrophic genome dysregulation due to the stochastic exchange of DSEs that occur between them to form translocations. Generally, the rejoining or recombining of a DSB can be considered in four distinct phases of engagement: (1) Initiation, which senses and secures DSEs; (2) Determination, which induces DNA damage response (DDR) signaling via post-translational modifications to support repair pathway engagement; (3) Intervention, which integrates steps necessary for ligation such as resecting DNA strands, synthesizing DNA, processing damaged ends, and/or aligning ends; and (4) Resolution, which ligates DNA strands and extricates remaining repair factors from DNA.

There are two primary DSB repair pathways. Homologous recombination (HR), found in all cellular life [8], is a high-fidelity, yet high-energy and time-consuming [9], repair process that requires a template sequence and is active in the $\mathrm{S} / \mathrm{G} 2$ cell cycle phases [10]. In contrast, eukaryotes and some bacteria/archaea species [11] possess non-homologous DNA end joining (NHEJ), which is classically described as a relatively rapid repair pathway that ligates both strands of two DNA ends [12,13]. NHEJ is active throughout interphase [14,15] and is regarded as the repair pathway of choice in G1-phase cells [10] with reasonably high fidelity; the generation of small insertions and deletions is influenced by the type of overhang generated and the type of base damage incurred [4,16-20]. Between these two repair 
pathway extremes lie additional, less understood, DSB repair pathways (i.e., single-strand annealing-SSA; alternative end joining-A-EJ) $[21,22]$ that may possess specialized functions in mammals and/or provide additional redundancy to ensure repair at the cost of decreased fidelity [18,23-26].

Recent studies have provided new insights into NHEJ and A-EJ that have implications for therapeutic applications involving DSB repair in quiescent and cycling cells [18,27-36]. In this review, we discuss DNA end-joining structures and mechanisms at different phases of engagement, with an emphasis on pre-replicative cell cycle states, evolutionary conservation, and repair pathway choice during $\mathrm{V}(\mathrm{D}) \mathrm{J}$ recombination.

\section{NHEJ Overview}

As a "rapid response" DSB repair pathway [37], NHEJ can complete ligation of compatible broken ends in minutes [9]. However, incompatible ends require more time, needing to resect, modify, and/or synthesize nucleotides prior to ligation [4,38-43]. All NHEJ reactions require the KU70 and KU80 ("Ku") DSE sensing complex and the XRCC4/Ligase IV ligation complex, which are considered core components to the NHEJ reaction (Figure 1). Their essentiality is best evidenced by evolutionary conservation down to yeast and in some bacterial and archaeal species $[11,44]$, the greatest sensitivity to ionizing radiation (IR) when absent in cells, and their requisite role to complete V(D)J recombination [45-52]. In this regard, other NHEJ and associated factors may serve essential functions that are context specific or are functionally redundant with varying individual impacts to the overall efficiency of the reaction (Figure 1).

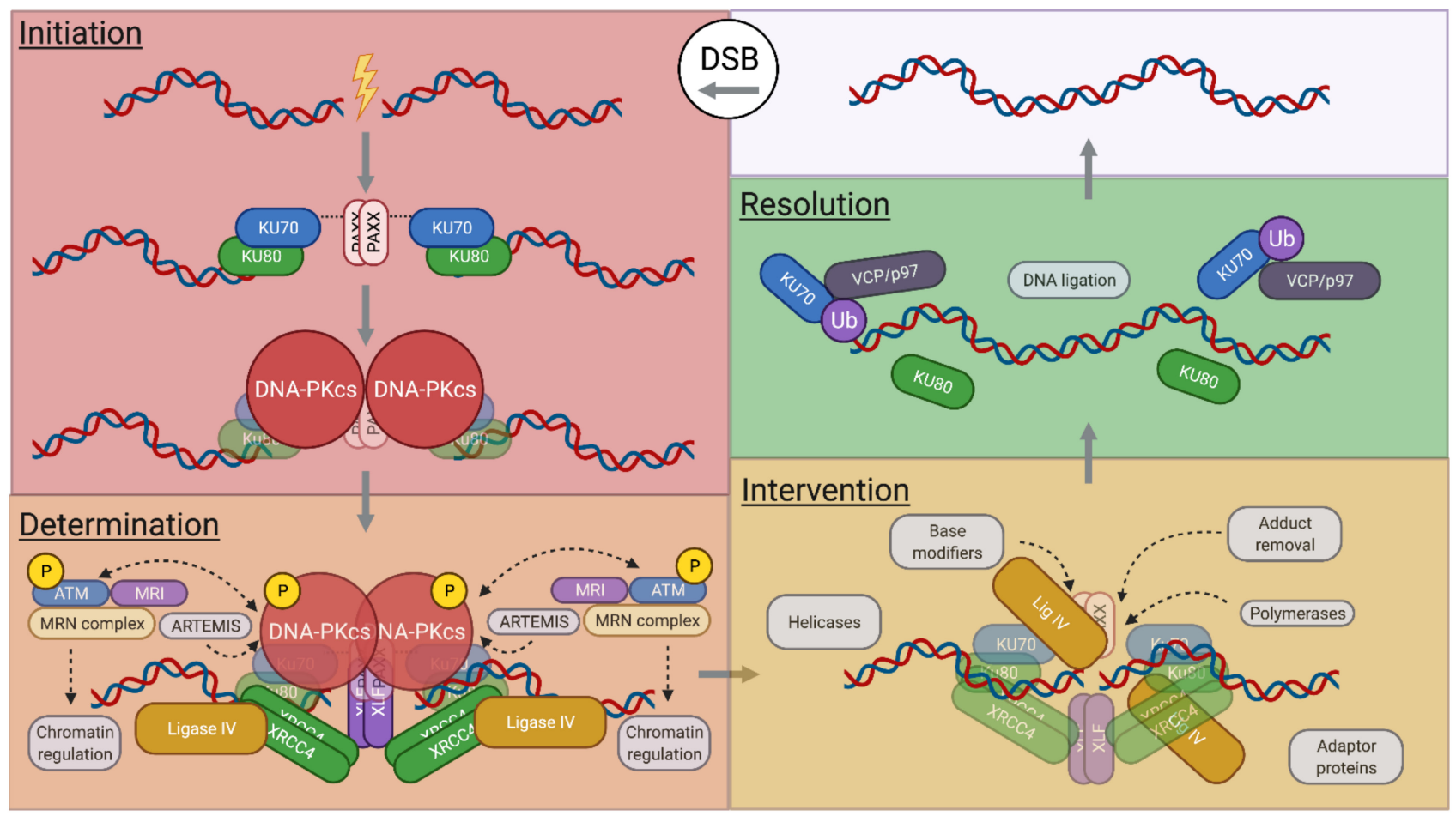

Figure 1. Four phases of DSB repair by NHEJ. Initiation: the NHEJ DSB sensing complex, Ku, recognizes and binds DSEs. PAXX dimers may keep DSEs paired by interaction with KU70. DNA-PKcs binds to Ku to form DNA-PK. Determination: DNA-PK is phosphorylated by ATM and vice versa; MRI mediates their interaction but no clear mechanism beyond binding. ATM and the MRN complex mediate chromatin remodeling of the neighboring chromatin to prime for repair pathway commitment. Phosphorylated DNA-PK activates ARTEMIS to open DNA hairpins and suppress DNA ligation during this process. Binding of XLF, XRCC4 and Ligase IV induces conformation changes to strengthen synapsis of paired DSEs. Intervention: hyper trans autophosphorylation induces release of DNA-PKcs and engagement for end compatibility using a toolkit of end-processing enzymes. Resolution: DSEs are ligated and constitutive damage signal dissolves as ubiquitinated $\mathrm{Ku}$ is removed from DNA by the ATPase VCP/p97. 


\subsection{NHEJ Initiation}

NHEJ senses DNA ends via the Ku complex [53]. The heterodimer is basket shaped, with each monomer encircling the DNA phosphate backbone [54]. Ku has high affinity for blunt ends [55] and a preference for the single-strand/double-strand (ss/dsDNA) interface in the context of ssDNA overhangs in vitro [56]. Ku loading onto ends will remove in its path damaged abasic or apurinic/apyrimidinic nucleotides from termini since it possesses $5^{\prime} \mathrm{dRP} / \mathrm{AP}$ lyase activity [42]. Ku serves as the prime loading complex for recruiting other NHEJ factors to process ends, as needed, and to complete ligation between DNA ends. $\mathrm{Ku}$ alone contributes to DSE synapsis in bacteria but has no discernable contribution in humans [57], therefore, requiring additional factors for synapsis. In this regard, the DNA-dependent protein kinase (DNA-PK) catalytic subunit (DNA-PKcs), conserved in metazoans, interacts with the C-terminus of Ku80 [58,59] (thus, forming the DNA-PK DDR holoenzyme (Figure 1)), creates conformational changes in DNA-PKcs to stabilize DNA binding and enable synapsis of paired DSEs [27,28,30,31]. Functions of DNA-PKcs as a loading complex and as a synaptic mediator between DSEs are prompted by autophosphorylation and activation of the kinase activity of DNA-PKcs via twisting and stretching [31].

\subsubsection{NHEJ “Long-Range" Synapsis}

Synapsis of paired DSEs by DNA-PK, as first observed by single-molecule Förster resonance energy transfer (smFRET) studies [60], is configured in "long range" (defined as DSE pairs that are offset by $>100 \AA)$ and may not require DNA-PK activation $[36,60]$. Recent cryo-EM suggest that synapsis of DNA-PK occurs by trans-swapping of Ku80 C-termini that interact with DNA-PKcs [27] (Figure 2) and may have additional functions beyond synapsis (e.g., priming DNA-PK activation by twisting and stretching of DNA-PKcs). A second "long-range" synapsis configuration determined by cryoEM [28,30], composed of DNA-PK with XRCC4-like factor (XLF) and XRCC4/Ligase IV is analogous to an earlier description of a closer synapse configuration than with DNA-PK alone [33,60,61]. Functionally, singlemolecule DNA tension studies indicate that the "long-range" DNA-PK synapse is highly transient but can be further stabilized by Paralog of XLF and XRCC4 (PAXX) [62], which can interact directly with Ku70 [63-65]. Further, XLF can increase synapsis duration of DNA-PK-bound ends only with XRCC4/Ligase IV [62]. In this context, XLF supports synapsis as a dimer [61] and requires at least one $\mathrm{Ku}$ binding motif of the dimer and a sufficiently long C-terminus to support NHEJ resolution [66]. Thus, there appear to be two "long-range" synapse configurations, one that is transient and connected by DNA-PK, and another that is more stable that includes XLF and XRCC4/Ligase IV. Since DNA-PKcs is not required for all NHEJ, additional structures that include PAXX and other proposed tethering factors $[67,68]$ may provide further insight into other possible early-stage synapse configurations (see model in Figure 2).

\subsubsection{NHEJ Filaments}

XLF and XRCC4 are also phosphorylated by Ataxia-Telangiectasia Mutated (ATM) and/or DNA-PK DDR kinases [69,70], which decrease DNA interaction [71] and enable formation of alternating helical filaments [72-76]. These XLF:XRCC4 helical filaments reportedly form around DNA in cells, likely initiating from the DSB [77], and allow Ku with DSE to diffuse more readily within the confines of the filament [78], functioning to support synapsis and to aid in aligning ends. It is noteworthy that IFFO1, a nucleoskeleton protein that interacts with A-type lamin intermediate filaments, also interacts with XRCC4 in a putative scaffold role to immobilize DSEs and suppress translocations [79], perhaps to limit the three-dimensional search space and stabilize synapsis. However, while this activity with intermediate filaments is not expected to be universal in all vertebrate cells-nuclear A-type lamins are only expressed in more differentiated cells [80] - this variance in repair outcomes across normal somatic cells can also impact many cancers with aberrant lamin expression [81]. 


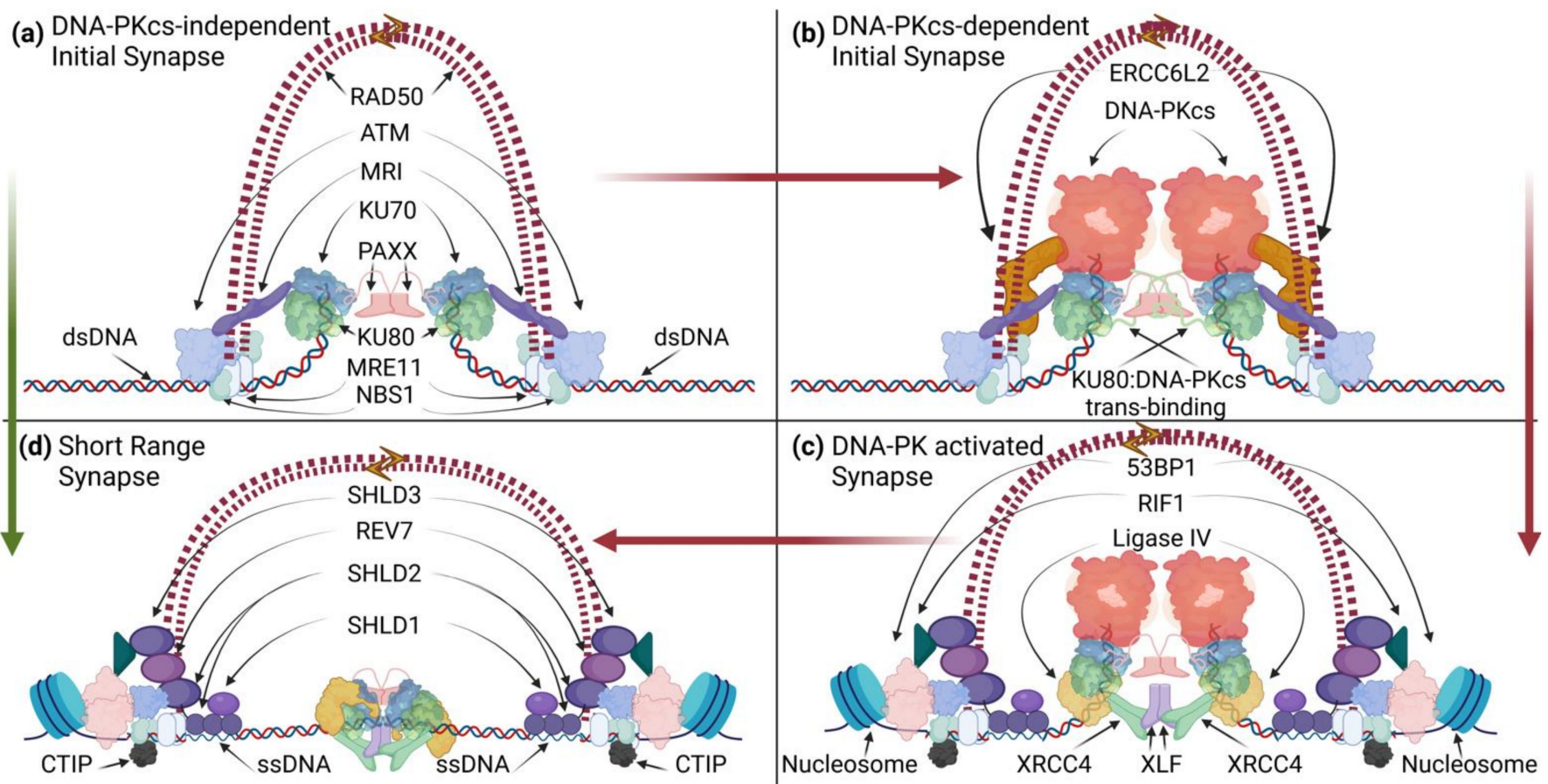

Figure 2. Model for dual-layer DSE pairing by NHEJ/DDR components in the G0/G1 phase. NHEJ proteins hold DSEs at the synapse while MRE11/RAD50 loops support DSE tethering a greater distance away from DNA ends. (a,b) Ku binds DSEs. PAXX dimerization may support synapsis across DSEs by KU70 interaction [62-65]. MRI connects KU70 to ATM signaling. Biophysical force transfer between synapsed ends, in response to Langevin Motion [82], signals constitutive twisting and stretching may activate ATM autophosphorylation and stabilize MRE11/RAD50 DNA binding through NBS1. (b) DNA-PKcs binds to Ku at end termini to form the DNA-PK holoenzyme. The C-terminal alpha helix of KU80 becomes bound to the opposite DNA-PKcs subunit to complete trans domain swapping and dimerization [27]. Stretching and twisting may prime for DNA-PK activation [31]. The presence of ERCC6L2 supports NHEJ functions, potentially in collaboration with MRI. (c) XLF dimer recruitment connects each DSE to flanking XRCC4 dimers and Ligase IV on each side [28,30]. The conformational shift reverts KU80 domain swapping, enabling ATM to activate DNA-PK and for DNA-PK to attenuate ATM activity to support NHEJ. NBS1/ATM chromatin signaling ultimately recruits 53BP1, RIF1, and the shieldin complex (SHLD1, SHLD2, REV7, and SHLD3) [83]. Biophysical detection of pairing may signal to commit to NHEJ. ATM phosphorylates CTIP (black, see (d)) to stimulate MRE11 nuclease activity. DNA-PK enables MRE11 endonuclease activity [32] to expose ssDNA for SHLD2 OB-fold domain binding (depicted here with $3^{\prime}$ strand nicking instead of $5^{\prime}$ strand nicking proposed for S/G2). (d) Complete DNA-PK trans autophosphorylation releases DNA-PKcs from the synapse, enabling transition to the short-range synapse [28,30]. Ligase IV becomes poised for ligation in a "close" synapse [36,84]. Note that NHEJ factors from (a) can readily proceed to the short-range configuration (green arrow; see (d)) in the absence of DNA-PKcs but may not be coordinated with MRN complex activities.

\subsubsection{NHEJ/DDR-Mediated Tethering}

Sustained DSE pairing of a DSB is necessary to ensure their rejoining, and redundant mechanisms to keep DSEs together likely exist beyond their synapsis by NHEJ factors. The ATM DDR kinase is widely known for suppressing translocations and supporting $\mathrm{V}(\mathrm{D}) \mathrm{J}$ recombination $[85,86]$. How exactly ATM supports end-tethering functions is not fully understood but may be related to its activities at the DSB. ATM operates at the DSB via interaction of NBS1, which serves adapter functions for the multi-functional MRE11/RAD50/NBS1 (MRN) complex which can be recruited to DSBs under different contexts [87-89]. At the DSB, the Modulator of Retroviral Infection (MRI; aka CYREN) connects DNA-PK to ATM thorough its N-terminal $\mathrm{Ku}$ binding motif to KU70 and its C-terminal XLF-like motif (XLM) to ATM [90]. MRI is thought to communicate repair pathway choice by suppressing NHEJ in the S/G2 cell cycle phases [91], and its presence in quiescent B cell progenitors may further stabilize KU70:PAXX interactions [90]. This 
stabilization could be related to why PAXX plays a more significant NHEJ role in the G0/G1 phase [92,93]. ERCC6L2, identified in recent genetic screens [94-96], is a helicase that is also recruited to DSBs by NBS1 [97] and interacts with DNA-PKcs [98] and MRI [95] where it impacts repair pathway choice in cycling cells [94]. In terms of evolutionary conservation, MRE11 and RAD50 are found in virtually all organisms, while ATM, NBS1, MRI, ERCC6L2, PAXX, DNA-PKcs, and XLF are conserved in most if not all (i.e., ATM, NBS1, XLF) eukaryotes [8,44,63,99-101]. Thus, MRE11/RAD50 (MR) must provide core functions to support all DSB repair [37]. How the above-described factors then regulate or coordinate with MR-related activities is not entirely clear.

MRE11 is a structure-specific nuclease that senses DNA ends and typically functions with RAD50, an ATPase with long coiled-coil domains and zinc hook that can slide on DNA and bypass nucleosomes [102]. As a heterotetramer, the MR complex can tether with other MR complexes using cohesin-/condensin-like open and closed loop configurations [103-105]. Thus, models have been proposed suggesting that putative DSE tethering functions through interlinked RAD50 molecules [103,104,106-108]. The significance of many MRN-associated interactions has been laid out genetically as combined deficiency, but not any single deficiency, of either ATM, MRI, DNA-PKcs, ERCC6L2, or PAXX with XLF significantly inhibiting NHEJ; where assayed, this NHEJ inhibition is comparable to that of core NHEJ deficiencies with respect to IR sensitivity and block in V(D)J recombination $[87,89,92,93,109-113]$. Therefore, both the role of XLF to support NHEJ synapsis and the putative role of the MR complex to support tethering by a mechanism that involves ATM/DNA-PK signaling suggest that their functional redundancy would include proximal synapsis and distal tethering mechanisms to stabilize DSE pairing by supporting DSB rejoining and suppressing translocations (Figure 2) and warrants further investigation.

\subsection{NHEJ Determination}

DNA damage signaling to flanking chromatin is coordinated by ATM and DNAPK, with ATM responsible for signal amplification using chromatin loop extrusion and diffusion [114,115]; reviews dedicated to chromatin remodeling and DSB movements in response to DNA damage are found here [116-118]. Ku and recruited NHEJ factors occupy DNA ends and can recruit end-processing enzymes as part of generating compatible ends for ligation $[18,39,119]$ while also suppressing resection enzymes that promote homologymediated repair pathways. Therefore, extraction of Ku from DSEs is necessary to complete repair by other pathways. Although the determination to switch from NHEJ to other repair pathways is minimal in G0/G1-phase cells compared to in the S/G2 phases, factors involved in this transition may be relevant for complex end processing with NHEJ or for supporting A-EJ. MRE11 is widely considered the nuclease to execute changes to DNA end access and to contribute to short-range resection. Normally, MRE11 cannot bind to DNA when interacting with ATP-bound RAD50 [120-123]. However, MRE11 $3^{\prime}$ to $5^{\prime}$ exonuclease activity $[124,125]$ is stimulated by the phosphorylated C-terminal binding protein (CtBP)interacting protein (CTIP) when recruited by NBS1 [126-128]. MRE11 also possesses endonuclease activity for either DNA strand in this active state but only near DNA ends that are blocked by bound protein (e.g., DNA-PK) [129] or with protein-DNA adducts in the $S$ phase when MRN is paired with phosphorylated CTIP and BRCA1 [130]. However, MRE11 exonuclease activity in G1-phase human cells also requires phosphorylated CTIP and BRCA1 in collaboration with NHEJ to repair complex ends from IR-induced DSBs [39]. In this regard, the context of CTIP phosphorylation can have different impacts to the level of resection and whether MRE11 endonuclease activity is stimulated [32]. Multiple CTIP phosphorylation sites exist and are differentially targeted by S/G2 CDKs [131], Ataxia-Telangeictasia and Rad3 related (ATR) [132], ATM [133,134], Polo-like kinase 3 [38], and DNA-PK [32].

Aside from promoting resection by CTIP phosphorylation, ATM also suppresses resection by initiating multi-stage recruitment of 53BP1, RIF1 and the Shieldin complex (composed of SHLD3, REV7, SHLD2, and SHLD1), which connects nearby chromatin 
to resected DNA near DSEs [6,83]. Resection in quiescent human and mouse cells are additionally regulated independently of 53BP1 by the dimerization partner, RB-like, E2F and multi-vulval class B (DREAM) complex components. Specifically, LIN37 cooperates with pRB, p107, and p130 to promote quiescence [135] and was identified in a genetic screen that induced resection of IR-generated DSBs in Ligase IV-deficient non-cycling progenitor B cells [29]. LIN37 functions to repress protein expression of key HR genes (i.e., BRCA1/2, BARD1, RAD51, BLM, and FANCD2) that can initiate resection in the G0 phase in its absence [29]. These striking findings suggest a clear differentiation of available DSB repair components between cycling G1 phase vs. quiescence and imply other non-cycling cell states [136-138] may also possess such differences.

\subsection{NHEJ Intervention}

DNA-PK can phosphorylate ATM to suppress its activity and promote NHEJ [139]. DNA-PK can also be activated via ATM trans-phosphorylation to suppress ligation [140], allowing for the recruitment of the ARTEMIS endonuclease by Ku [141]. ARTEMIS, activated by DNA-PK, opens DNA hairpins [142] and processes other DNA end structures [143] to form $3^{\prime}$ overhangs $[16,143]$. DNA-PK autophosphorylation associated with hairpin-sealed ends is stepwise, with full autophosphorylation present once the hairpin is opened [144]. Complete DNA-PK trans autophosphorylation in the "long-range" synapse variant with XLF and XRCC4/Ligase IV uncouples DNA-PKcs from the synapse to form a "short-range" synapse $[28,30]$ that facilitates, as needed, processing enzymes, polymerases and tethering factors (i.e., TDP1, PNKP, APTX, POL $\mu$, POL $\lambda$, TDT, APLF, WRN) $[12,67,68,145]$ to support end alignment and ligation. This is consistent with mouse studies of kinase dead DNAPKcs linking trans autophosphorylation with completion of hairpin-ended NHEJ $[140,146]$ and provides insight into the DNA-PKcs-independent mechanisms of NHEJ. In this latter context, DSEs that are held in a transient "flexible" lateral-ended synapse by core NHEJ factors become aligned end to end as a stable "close" synapse in the presence of either PAXX or XLF $[36,84]$ and may represent, in part, precursor or variant conformations of the "short-range" synapse [77].

\subsection{NHEJ Resolution}

Aligned and compatible ends are then ligated by Ligase IV. Although the trigger to initiate post-ligation dissociation is not known, extraction of $\mathrm{Ku}$ rings from repaired DNA is the crucial linchpin for NHEJ dissociation. KU70 phosphorylation destabilizes end affinity in association with the transition to HR [147] but does not appear to be important for extraction from intact DNA. Instead, K48-linked polyubiquitination on multiple sites of KU80, and in some cases KU70 (by RNF126 [148], RNF8 [149-151] or NEDD8dependent [152] E3 ligases)—RNF138 does this only in the S/G2 phases [153,154]-leads to extraction from chromatin [148] by the VCP/p97 AAA+ ATPase [155] (Figure 1). In this regard, chromatin-modified DNA damage signals remain despite NHEJ ligation until Ku is extracted by p97 [155], clearly demonstrating that Ku extraction must first occur before chromatin damage signals are reverted. Uncoupling MRN activation on newly repaired DNA also requires ubiquitination of MRE11 [156] by VCP/p97 [157].

A speculative G0-phase NHEJ and DDR support model that integrates recent findings would include the following steps: (1) Ku or DNA-PK synapsis that includes PAXX and support from MRI, ATM, ERCC6L2, and the MRN complex, primarily functioning to keep ends synapsed until XLF and XRCC4/Ligase IV are recruited to form the more stable "long-range" (with DNA-PK) or "short-range" synapse (with Ku) [27,28,30,31]. Hyperphosphorylation of XLF and XRCC4 stabilizes filaments around Ku-bound DSEs may support synapsis [71], and MRN may coordinate with the Shieldin complex to limit resection and support synapsis. (2) Activated ARTEMIS would operate in a "long-range" synapse that includes XLF and XRCC4/Ligase IV [144], with accessory NHEJ factors acting on ends in "short range" as a laterally arrayed "flexible" synapse [84] after DNA-PKcs 
leaves the complex. (3) The various processing intermediates then structurally converge to a common "close" synapse for ligation by Ligase IV (Figure 2).

\section{A-EJ Overview}

A-EJ can be defined as end joining that occurs in the absence of core NHEJ factors, and many studies have implicated participating factors [15,18,24,34,158-186]. Most notable in recent years is polymerase theta (POL $\theta)[163,170,182]$, a multipurpose polymerase with RNA-templated DNA repair capabilities [187] that is upregulated in cancers $[24,167,188]$. Interpreting A-EJ contributions in the S/G2 cell cycle phases can be difficult since there are specialized repair processes and repair pathway/component redundancies that are still awaiting full elucidation $[161,171,175,184,189,190]$. Unlike NHEJ factors, which are mostly exclusive, many implicated A-EJ factors also participate in base excision repair (BER) and nucleotide excision repair (NER) [191], with commonly structured repair intermediate parallels that also extend to Okazaki fragment ligation during lagging strand DNA synthesis [192-194]. Although cells exposed to lesion-promoting DNA damage from IR and chemotherapeutics (e.g., interstrand crosslinks) would rely on both single- and doublestrand DNA repair mechanisms, ascribing a physiological role to A-EJ has remained elusive due to the predominance and efficiency of NHEJ and HR. Thus, A-EJ may be regarded as inadvertent ultimate backup DSB repair pathways to prevent the persistence of DSEs [195].

\subsection{A-EJ Pathways and Cell Cycle Dependence}

While A-EJ is still not fully understood, recent studies with murine progenitor B cells identified separable A-EJ pathways [18,34]. In the G0 phase, the absence of $\mathrm{Ku}$, reveals a bona fide A-EJ pathway separate from NHEJ factor engagement [18] and employs the XRCC1/DNA Ligase III $\alpha$ complex [172] since DNA Ligase I is not active in the G0 phase [18,196-199]; the alternative splice form that does not include XRCC1 binding, Ligase III $\beta$, does not localize to the nucleus and is essential for mitochondrial DNA repair [172]. Correspondingly, A-EJ of targeted DSEs in the absence of the NHEJ ligation complex is blocked in the G0 phase. This demonstrates the level of NHEJ predominance over AEJ [18,34] and explains why Ku deficiency can rescue the embryonic lethality of Ligase IV deficiency [200]. However, cells with unrepaired G0-phase DSBs, but then permitted to reenter cycling phases and bypass cell cycle checkpoints [201,202], can use an NHEJ-variant A-EJ pathway (i.e., requiring extraction of $\mathrm{Ku}$ and NHEJ machinery from DSEs) that is dependent on POL $\theta$ [34]. Surprisingly, POL $\theta$ does not contribute to G0-phase A-EJ since it is not expressed during quiescence [34]. Thus, a working model for bona fide core A-EJ factors would include PARP1, MRE11, and XRCC1/Ligase III $\alpha$.

\subsection{G0-Phase A-EJ Initiation and Determination}

In non-cycling progenitor $\mathrm{B}$ cells, Ku suppresses A-EJ, rendering ends more susceptible to resection and A-EJ in its absence [18]. Similar to Ku, poly(ADP-ribose) polymerase 1 (PARP1) is a rapid responder to DSBs $[174,203]$. PARP1 senses and secures DNA nicks, ssDNA patches, and DSEs as part of its multiple roles in BER, NER, and A-EJ [204]. PARP1 is 10-fold more abundant than its functionally overlapping relative, PARP2 [12]. While no clear orthologs have been described, poly(ADP-ribosyl)ation is found in bacteria and archaea [205]. Individual gene deficiencies in mice are viable; however, combined deficiencies of PARP1/PARP2, PARP1/KU80, or PARP1/ATM are early-stage embryonic lethal [206-208], underscoring the significance of PARP1 in supporting DNA repair and collaborating with the DDR. PARP1 generates poly(ADP)ribose (PAR) adducts on proteins, can crosslink to DNA [209] and can recruit MRE11 and NBS1 to DSEs [88], where MRE11 may function to bridge ends rather than promote resection [88,103,210] (Figure 3). CTIP can promote A-EJ in the absence of $\mathrm{Ku}$ in cycling cells [185], multimerize into filaments [211,212] and support end hybridization [213]. As discussed earlier for NHEJ [103,104,106-108], the MR complex may also provide end-tethering functions for G0-phase A-EJ. However, without DNA-PK present, short-range resection occurs [18] and tethering functions may 
be affected by the ATR DDR kinase $[132,214,215]$, which is recruited to the ss/dsDNA interface to sustain and coordinate repair even in the G1 phase [214,215]. In this context, it is not clear whether other resection enzymes or inhibitors function in the G0 phase [216-221].

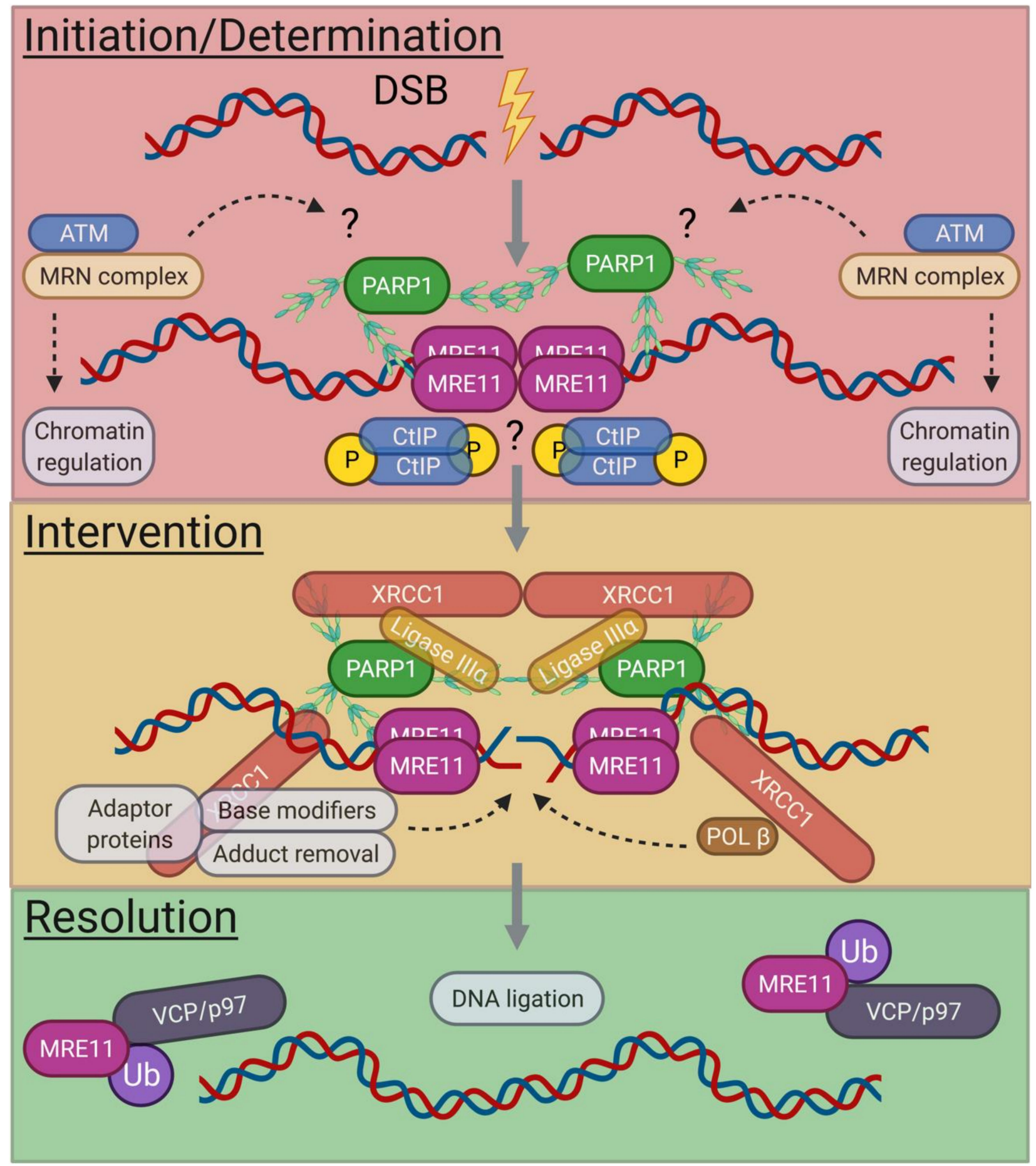

Figure 3. A speculative model for DSB repair by A-EJ in G0-phase cells. Quiescent B cell progenitors do not express POL $\theta$ and DNA Ligase I and instead use short-patch BER machinery (PARP1, XRCC1, Ligase III $\alpha$, POL $\beta$, etc.) to complement MRE11 and other MRN-related DDR and tethering functions. Other factors (e.g., TREX1 and CTIP) may support A-EJ and require further investigation. After DNA ligation, MRE11 is ubiquitinated [157], allowing for removal of MRE11 and associated complexes from DNA and dissolution of DNA damage signals. 


\subsection{G0-Phase A-EJ Intervention and Resolution}

As with BER/NER, PARylation serves to recruit additional repair factors and support end tethering. XRCC1 recruitment and binding to PAR [222] can suppress excessive PARylation in the context of BER [223] and may similarly apply for G0-phase A-EJ. XRCC1 is a scaffold protein that brings in, most notably, polymerase beta (POL $\beta$ ) and DNA Ligase III $\alpha$ (Figure 3). DNA Ligase III is conserved only in vertebrates [172], whereas POL $\beta$ belongs to the Pol X family of polymerases along with NHEJ co-factors POL $\lambda$, POL $\mu$, and TDT that all arose from a single precursor gene in bacteria [224]. When phosphorylated by casein kinase 2 (CK2), XRCC1 also recruits a trio of factors: Polynucleotide kinase $3^{\prime}$ phosphatase (PNKP) to prepare ends for ligation/polymerization, Aprataxin (APTX) to remove adducts from failed ligation $[40,204]$, and Aprataxin and PNK-like factor (APLF), which does not have a definitive role with XRCC1 yet [225]. Intriguingly, all three can function in NHEJ, where they also bind to CK2-phosphorylated XRCC4 [226,227].

Together, the above referenced factors are implicated in "simple" or short-patch BER that is typified with single-nucleotide replacement or small gap filling $[40,228]$ and may operate in a similar manner at synapsed DSEs for A-EJ (Figure 3). While the exact stepwise mechanism remains to be determined, extrapolation of BER functions is plausible. To handle incompatible ends, a polymerase with proof-reading capability would suffice. Unfortunately, POL $\beta$ lacks $3^{\prime}$ to $5^{\prime}$ proof reading, is error prone, and has a relatively short range of processivity $(<7 \mathrm{bp})[228,229]$. However, TREX 1 is a $3^{\prime}$ to $5^{\prime}$ exonuclease [230] that can translocate to the nucleus under genotoxic stress and interact with PARP1 [231] to trim mispaired $3^{\prime}$ termini of DSEs, potentially generated by POL $\beta$. Thus, the mutagenic property of POL $\beta$ coupled with the trans "proof reading" of TREX1 would address how incompatible ends are managed. Indeed, multiple attempts to ligate or modify nucleotide with adducts from failed ligation of mismatched base pairing may lead to blunting of ends. This testable model also supports the observed accumulation of unrepaired DSEs and increased utilization of direct joins for G0-phase A-EJ [18].

\section{End-Joining Pathway Utilization during V(D)J Recombination}

Deficiency of core NHEJ factors blocks B and T lymphocyte development [45-47,51,201,232], resulting in a severe combined immunodeficiency (SCID). This defect is due to a failure to complete $\mathrm{V}(\mathrm{D}) \mathrm{J}$ recombination: a cut and paste reaction in the G0/G1 phase that brings together individual Variable (V) Diversity (D) and Joining (J) gene segments spread across several megabases in immunoglobulin (Ig) and T cell receptor (TCR) loci (Figure 4).

\section{1. $V(D) J$ Recombination}

Recombination-Activating Gene (RAG) proteins (RAG1 and RAG2; "RAG") are a domesticated transposase which initiate the cleavage event of $V(D) J$ recombination but lost their ability to complete transposition $[35,233,234]$. RAG is heterotetramerically primed to seek a recombination sequence pair which, when recognized, provides the signal to initiate V(D)J recombination. Recombination Signal Sequences (RSSs) are composed of either a 12 bp or $23 \mathrm{bp}$ non-conserved spacer sequence flanked on the incision side by a conserved heptameric "CAC/GTG" book-ended palindrome and an AT-rich nonamer on the opposite side. A 12/23RSS pairing by RAG1 is required and enforced by RAG2 [235] for RAG to coordinate a nick and subsequent double-strand cleavage at the interface between each RSS and their adjacent gene segment [35,236]. Each pair of DSEs formed are asymmetric with one blunt RSS end and one hairpin-sealed coding end, held in a post-cleavage synaptic complex (PSC). The RAG PSC collaborates with NHEJ to align the synapsis and eventual repair of coding ends, and separately RSS ends, that is characteristic of $\mathrm{V}(\mathrm{D}) \mathrm{J}$ recombination (Figure 4) [18]. 


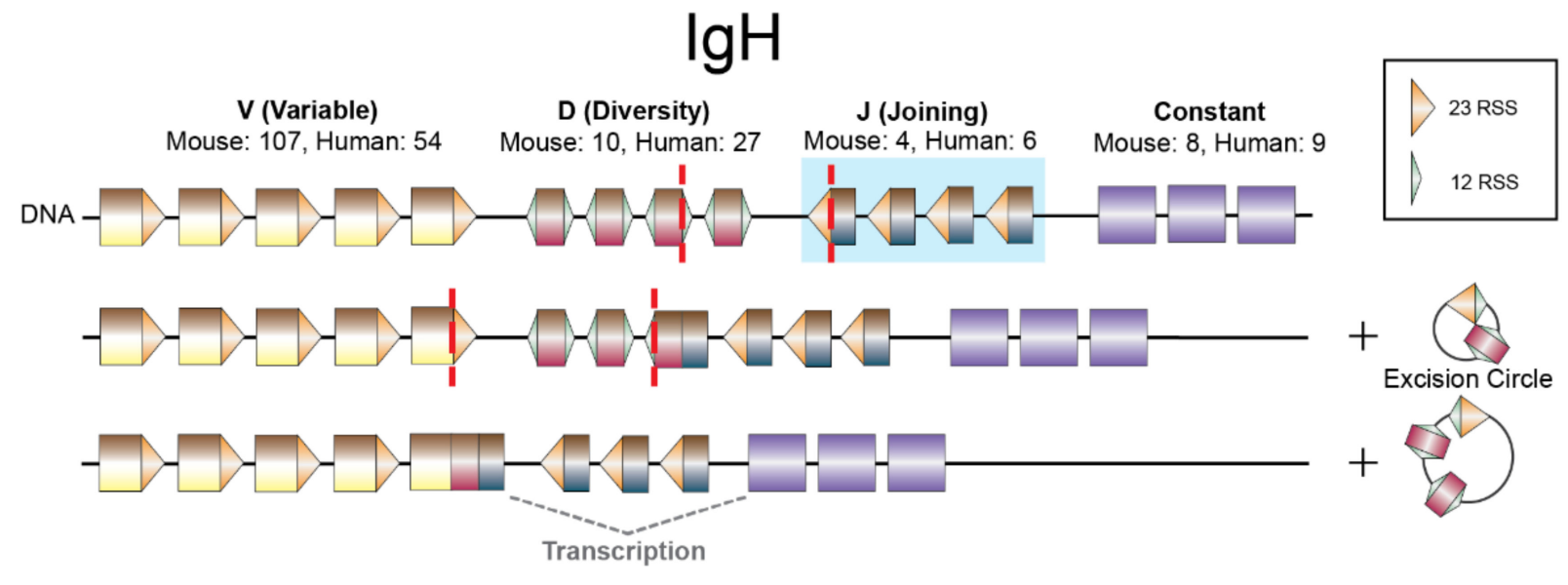

$\lg K$
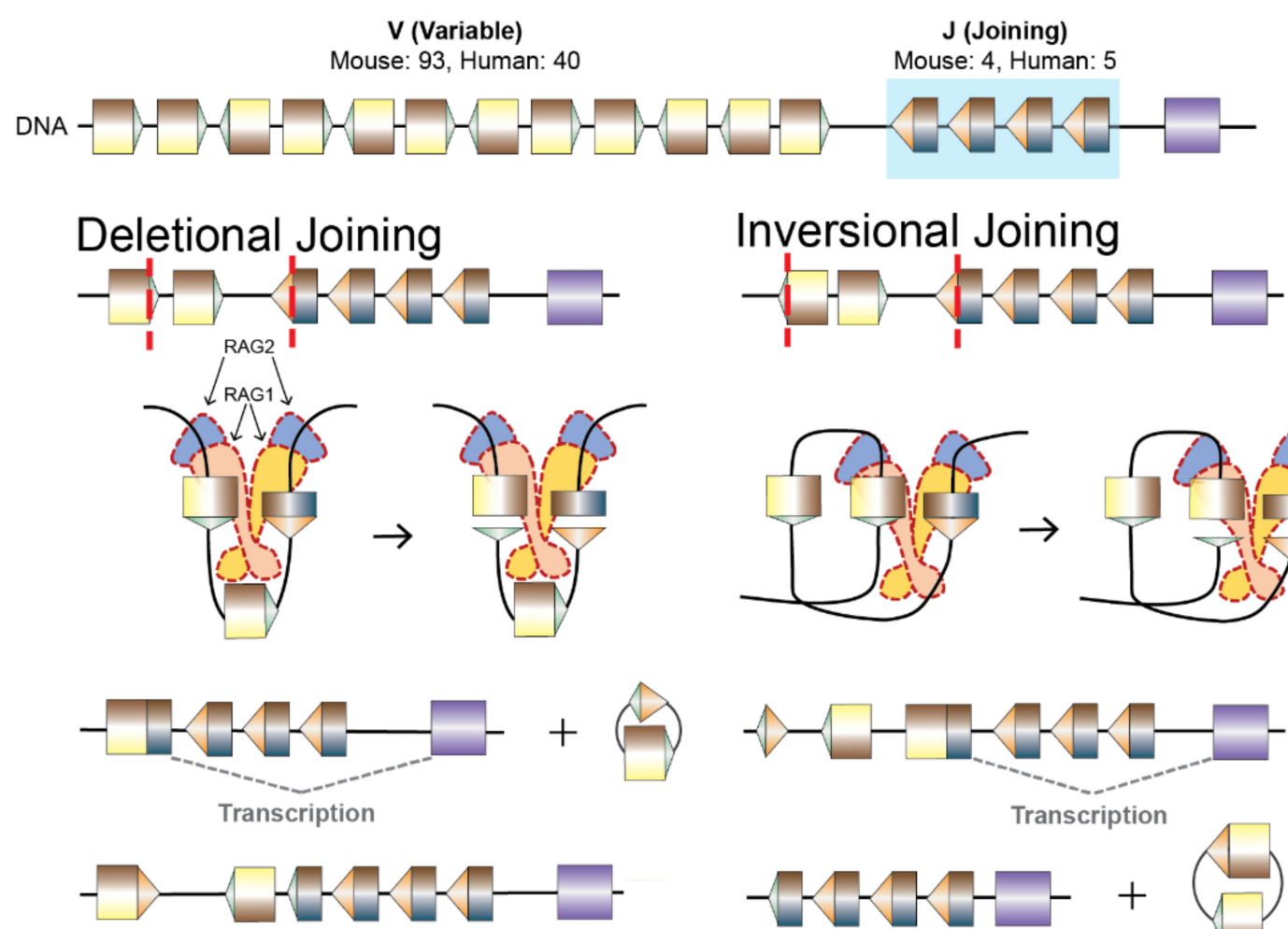

(RSS Inversion)
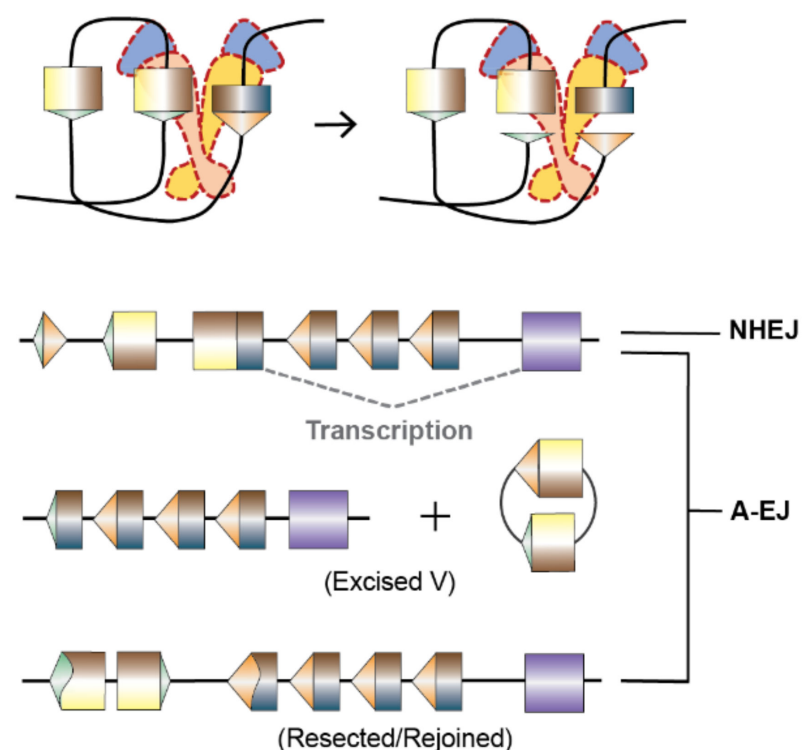

Figure 4. V(D)J recombination by NHEJ and V(D)J-like joining by A-EJ. The IgH and Igk loci contain V, D, J and V, J gene segments that are used to generate the variable region of antigen receptors. Top: The IgH locus contains multiple constant region exons that are selected later in activated mature B cells during IgH class switch recombination to diversify antibody effector functions. Functional gene segments and exons for mouse and human Ig loci are enumerated from IMGT.org [237,238]. IgH undergoes D to J recombination first, followed by V to DJ recombination [239]; each recombination event generates excision circles of intervening DNA. In contrast, Igא undergoes V to J recombination but V gene segments are arrayed in either a deletional or inversional orientation with respect to the J gene segments, resulting in deletions with excision circles (left) or retention of intervening sequence by inversion (right). V(D)J recombination begins with RAG1/2 (RAG) loading into recombination centers located in J gene segment clusters (blue box); the IgH RC also contains one D gene 
segment (not shown) [240]. RAG, with bound RC-associated RSS, directionally scans for 12/23 RSS pairing as DNA loops are extruded through CTCF/cohesin loop anchors [239]. RAG generates two DSBs to form two blunt RSS ends and two hairpin-sealed gene segment (coding) ends held in a PSC. NHEJ will proceed to open hairpins on coding ends, process, and join them, whereas RSS ends will be simply ligated, to complete V(D)J recombination. In the absence of the NHEJ DSB sensor, $\mathrm{Ku}$, but not in the absence of the NHEJ ligation complex, A-EJ gains access to RAG DSEs, but pairing is random, resulting in $\mathrm{V}(\mathrm{D}) \mathrm{J}$-like translocations, translocation of an RSS end to a different coding end, and resected/rejoined junctions associated with the initial RAG DSBs [18]. Thus, the rate of suitably paired antigen receptors (e.g., IgH:Igk) would be very low and explains the leaky SCID phenotype of Ku-deficient mice [47].

The current model posits that RAG activation at recombination centers (RCs) [241] bind one RC-associated RSS with one RAG1/2 heterodimer and then proceeds to partner with a compatible RSS in the RC [240] or by scanning the appropriate DNA strand for a second RSS or potentially an off-target "CAC" motif $[240,242,243]$ as chromatin loops are actively extruded [239,240,242-247]. However, recent single-molecule dynamics imaging suggests that RSS pairing in chromatin may be highly infrequent with low antigen receptor locus occupancy and transient residence times that would suggest sampling only a fraction of an extruded loop at any given time [248].

\subsection{A-EJ of RAG DSEs, RAG2 Functions, and Repair Pathway Choice}

A-EJ of RAG DSEs in quiescent $B$ cell progenitors is handled similarly to endonucleasetargeted DSBs, with resection of ends and substantial levels of coding joins (mostly nonproductive) specifically for Ku deficiency [18], and not for XRCC4/Ligase IV deficiency $[18,34]$. These findings are also consistent with their respective leaky vs. complete SCID mouse phenotypes [45,47]. However, A-EJ of coding and RSS ends is not directed, as with NHEJ involvement, and instead results in unbiased joining of coding and RSS ends by a translocation-based mechanism that involves undirected end synapsis, likely after the PSC no longer sustains binding of all four ends (Figure 4) [18]. In this regard, deficiency in ATM or mutations in MRN can form hybrid joins (joining of an RSS end with another coding end) are formed in comparable frequency to coding joins when using a recombination reporter designed for inversional joins $[133,249,250]$. Hybrid joins would seemingly be the result of impaired MR complex DNA end tethers while in association with the RAG PSC and is consistent with an NHEJ functional redundancy that serves to maintain DSE pairing (Figure 2); whether such ends are repaired by aberrant NHEJ or by A-EJ remain to determined.

RAG is thought to shepherd its DSEs to NHEJ [134] rather than A-EJ since aberrant end joining and genome instability were detected by RAG2 C-terminal truncation mutations in the presence or absence of NHEJ [251-254]. Despite recent insights into G0/G1-phase A-EJ, it remains unclear how RAG2 C-terminal truncation promotes A-EJ. The RAG2 C-terminus, a partially acquired coincidence with a notable evolutionary stage of RAG domestication [35,234], restricts activity to the G0/G1 phase [255-257] and contains two domains: an acidic hinge and a plant homeodomain (PHD) zinc finger, that further modulate RAG activity. The acidic hinge is an intrinsically disordered domain, with negatively charged residues that stabilize the PSC [258] and additionally autoinhibits RAG activity [259,260]. The PHD finger binds histone H3K4me3 marks that are characteristic of transcription start sites and RCs located in J gene segment clusters of Ig and T cell receptor genes [261,262]; binding H3K4me3 marks disables its autoinhibition $[259,260]$. Thus, while the absence of the RAG2 C-terminus regulatory components is compatible with V(D)J recombination in mice, albeit with significantly impaired efficiency [263], the aberrant RAG-induced DSEs in S/G2 cell cycle phases may be subject to repair beyond NHEJ. Whether this repair involves end-joining pathways, is a result of restored DNA transposition [35], or a combination of both possibilities remains to be determined. 


\section{Conclusions}

Many new insights into DNA end-joining mechanisms have come to light in recent months. Multi-subunit structures and single-molecule studies of NHEJ and DDR complexes have helped to piece together more of the rules of how the DSB repair machinery engages DSEs to synergize with genetic interpretations of repair factor deficiencies. Likewise, the determination of multiple A-EJ pathways, impact of A-EJ to V(D)J recombination, and differential regulation of HR gene expression will necessitate a re-evaluation of prior studies that applied G1- vs. G0-phase approaches to measure repair outcomes that should additionally encapsulate DNA excision repair pathways. More broadly, leveraging recent insights to identify synthetic genes for mitotically dormant cancer cells that contribute to recurrence and metastasis would be complementary to many existing therapies. They also highlight novel genome editing approaches for non-cycling cells, an important feature that most of our somatic cells share. However, central to our understanding of DNA endjoining pathways and toward developing effective therapeutics is exploring the nuanced differences in DNA repair between mice and humans [264-270].

Author Contributions: Conceptualization, R.L.F.; project administration, R.L.F.; resources, R.L.F., C.S., J.M. and J.L.W.; supervision, R.L.F. and J.L.W.; visualization, R.L.F., C.S. and J.M.; writingoriginal draft, R.L.F.; writing-review and editing, R.L.F., C.S., J.M. and J.L.W. All authors have read and agreed to the published version of the manuscript.

Funding: R.L.F. is a V Scholar for the V Foundation for Cancer Research (V2019-003).

Institutional Review Board Statement: Not applicable.

Informed Consent Statement: Not applicable.

Data Availability Statement: Not applicable.

Acknowledgments: We thank Marie Le Bouteiller, Carlos Origel, Paul Barghouth, and Meg Fuentes for careful reading and critical feedback. Figures 1-3 were created with BioRender.com.

Conflicts of Interest: The authors declare no conflict of interest.

\section{References}

1. Curtin, N.J. DNA repair dysregulation from cancer driver to therapeutic target. Nat. Rev. Cancer 2012, 12, 801-817. [CrossRef] [PubMed]

2. Lieber, M.R. Mechanisms of human lymphoid chromosomal translocations. Nat. Rev. Cancer 2016, 16, 387-398. [CrossRef] [PubMed]

3. Martinez, P.; Blasco, M.A. Telomere-driven diseases and telomere-targeting therapies. J. Cell Biol. 2017, 216, 875-887. [CrossRef] [PubMed]

4. Menon, V.; Povirk, L.F. End-processing nucleases and phosphodiesterases: An elite supporting cast for the non-homologous end joining pathway of DNA double-strand break repair. DNA Repair 2016, 43, 57-68. [CrossRef] [PubMed]

5. Chanut, P.; Britton, S.; Coates, J.; Jackson, S.P.; Calsou, P. Coordinated nuclease activities counteract Ku at single-ended DNA double-strand breaks. Nat. Commun. 2016, 7, 12889. [CrossRef]

6. Mirman, Z.; de Lange, T. 53BP1: A DSB escort. Genes Dev. 2020, 34, 7-23. [CrossRef]

7. Willis, N.A.; Frock, R.L.; Menghi, F.; Duffey, E.E.; Panday, A.; Camacho, V.; Hasty, E.P.; Liu, E.T.; Alt, F.W.; Scully, R. Mechanism of tandem duplication formation in BRCA1-mutant cells. Nature 2017, 551, 590-595. [CrossRef]

8. Marshall, C.J.; Santangelo, T.J. Archaeal DNA Repair Mechanisms. Biomolecules 2020, 10, 1472. [CrossRef]

9. Mao, Z.; Bozzella, M.; Seluanov, A.; Gorbunova, V. Comparison of nonhomologous end joining and homologous recombination in human cells. DNA Repair 2008, 7, 1765-1771. [CrossRef]

10. Karanam, K.; Kafri, R.; Loewer, A.; Lahav, G. Quantitative live cell imaging reveals a gradual shift between DNA repair mechanisms and a maximal use of HR in mid S phase. Mol. Cell 2012, 47, 320-329. [CrossRef]

11. Sharda, M.; Badrinarayanan, A.; Seshasayee, A.S.N. Evolutionary and Comparative Analysis of Bacterial Nonhomologous End Joining Repair. Genome Biol. Evol. 2020, 12, 2450-2466. [CrossRef] [PubMed]

12. Chang, H.H.Y.; Pannunzio, N.R.; Adachi, N.; Lieber, M.R. Non-homologous DNA end joining and alternative pathways to double-strand break repair. Nat. Rev. Mol. Cell Biol. 2017, 18, 495-506. [CrossRef] [PubMed]

13. Scully, R.; Panday, A.; Elango, R.; Willis, N.A. DNA double-strand break repair-pathway choice in somatic mammalian cells. Nat. Rev. Mol. Cell Biol. 2019, 20, 698-714. [CrossRef] [PubMed] 
14. Rothkamm, K.; Kruger, I.; Thompson, L.H.; Lobrich, M. Pathways of DNA double-strand break repair during the mammalian cell cycle. Mol. Cell Biol. 2003, 23, 5706-5715. [CrossRef]

15. Sfeir, A.; de Lange, T. Removal of shelterin reveals the telomere end-protection problem. Science 2012, 336, 593-597. [CrossRef] [PubMed]

16. Chang, H.H.Y.; Watanabe, G.; Gerodimos, C.A.; Ochi, T.; Blundell, T.L.; Jackson, S.P.; Lieber, M.R. Different DNA End Configurations Dictate Which NHEJ Components Are Most Important for Joining Efficiency. J. Biol. Chem. 2016, 291, 24377-24389. [CrossRef] [PubMed]

17. Lemos, B.R.; Kaplan, A.C.; Bae, J.E.; Ferrazzoli, A.E.; Kuo, J.; Anand, R.P.; Waterman, D.P.; Haber, J.E. CRISPR/Cas9 cleavages in budding yeast reveal templated insertions and strand-specific insertion/deletion profiles. Proc. Natl. Acad. Sci. USA 2018, 115, E2040-E2047. [CrossRef]

18. Liang, Z.; Kumar, V.; Le Bouteiller, M.; Zurita, J.; Kenrick, J.; Lin, S.G.; Lou, J.; Hu, J.; Ye, A.Y.; Boboila, C.; et al. Ku70 suppresses alternative end joining in G1-arrested progenitor B cells. Proc. Natl. Acad. Sci. USA 2021, 118, e2103630118. [CrossRef]

19. Pryor, J.M.; Waters, C.A.; Aza, A.; Asagoshi, K.; Strom, C.; Mieczkowski, P.A.; Blanco, L.; Ramsden, D.A. Essential role for polymerase specialization in cellular nonhomologous end joining. Proc. Natl. Acad. Sci. USA 2015, 112, E4537-E4545. [CrossRef] [PubMed]

20. Waters, C.A.; Strande, N.T.; Pryor, J.M.; Strom, C.N.; Mieczkowski, P.; Burkhalter, M.D.; Oh, S.; Qaqish, B.F.; Moore, D.T.; Hendrickson, E.A.; et al. The fidelity of the ligation step determines how ends are resolved during nonhomologous end joining. Nat. Commun. 2014, 5, 4286. [CrossRef] [PubMed]

21. Bhargava, R.; Onyango, D.O.; Stark, J.M. Regulation of Single-Strand Annealing and its Role in Genome Maintenance. Trends Genet. 2016, 32, 566-575. [CrossRef]

22. Sallmyr, A.; Tomkinson, A.E. Repair of DNA double-strand breaks by mammalian alternative end-joining pathways. J. Biol. Chem. 2018, 293, 10536-10546. [CrossRef] [PubMed]

23. Bhowmick, R.; Minocherhomji, S.; Hickson, I.D. RAD52 Facilitates Mitotic DNA Synthesis Following Replication Stress. Mol. Cell 2016, 64, 1117-1126. [CrossRef]

24. Liu, Q.; Palomero, L.; Moore, J.; Guix, I.; Espin, R.; Aytes, A.; Mao, J.H.; Paulovich, A.G.; Whiteaker, J.R.; Ivey, R.G.; et al. Loss of TGFbeta signaling increases alternative end-joining DNA repair that sensitizes to genotoxic therapies across cancer types. Sci. Transl. Med. 2021, 13, eabc4465. [CrossRef] [PubMed]

25. Morales, M.E.; White, T.B.; Streva, V.A.; DeFreece, C.B.; Hedges, D.J.; Deininger, P.L. The contribution of alu elements to mutagenic DNA double-strand break repair. PLoS Genet. 2015, 11, e1005016. [CrossRef]

26. Sotiriou, S.K.; Kamileri, I.; Lugli, N.; Evangelou, K.; Da-Re, C.; Huber, F.; Padayachy, L.; Tardy, S.; Nicati, N.L.; Barriot, S.; et al. Mammalian RAD52 Functions in Break-Induced Replication Repair of Collapsed DNA Replication Forks. Mol. Cell 2016, 64, 1127-1134. [CrossRef]

27. Chaplin, A.K.; Hardwick, S.W.; Liang, S.; Kefala Stavridi, A.; Hnizda, A.; Cooper, L.R.; De Oliveira, T.M.; Chirgadze, D.Y.; Blundell, T.L. Dimers of DNA-PK create a stage for DNA double-strand break repair. Nat. Struct. Mol. Biol. 2021, $28,13-19$. [CrossRef]

28. Chaplin, A.K.; Hardwick, S.W.; Stavridi, A.K.; Buehl, C.J.; Goff, N.J.; Ropars, V.; Liang, S.; De Oliveira, T.M.; Chirgadze, D.Y.; Meek, K.; et al. Cryo-EM of NHEJ supercomplexes provides insights into DNA repair. Mol. Cell 2021, 81, 3400-3409.e3. [CrossRef]

29. Chen, B.R.; Wang, Y.; Tubbs, A.; Zong, D.; Fowler, F.C.; Zolnerowich, N.; Wu, W.; Bennett, A.; Chen, C.C.; Feng, W.; et al. LIN37-DREAM prevents DNA end resection and homologous recombination at DNA double-strand breaks in quiescent cells. eLife 2021, 10, e68466. [CrossRef]

30. Chen, S.; Lee, L.; Naila, T.; Fishbain, S.; Wang, A.; Tomkinson, A.E.; Lees-Miller, S.P.; He, Y. Structural basis of long-range to short-range synaptic transition in NHEJ. Nature 2021, 593, 294-298. [CrossRef]

31. Chen, X.; Xu, X.; Chen, Y.; Cheung, J.C.; Wang, H.; Jiang, J.; de Val, N.; Fox, T.; Gellert, M.; Yang, W. Structure of an activated DNA-PK and its implications for NHEJ. Mol. Cell 2021, 81, 801-810.e3. [CrossRef]

32. Deshpande, R.A.; Myler, L.R.; Soniat, M.M.; Makharashvili, N.; Lee, L.; Lees-Miller, S.P.; Finkelstein, I.J.; Paull, T.T. DNAdependent protein kinase promotes DNA end processing by MRN and CtIP. Sci. Adv. 2020, 6, eaay0922. [CrossRef] [PubMed]

33. Stinson, B.M.; Moreno, A.T.; Walter, J.C.; Loparo, J.J. A Mechanism to Minimize Errors during Non-homologous End Joining. Mol. Cell 2020, 77, 1080-1091.e8. [CrossRef] [PubMed]

34. Yu, W.; Lescale, C.; Babin, L.; Bedora-Faure, M.; Lenden-Hasse, H.; Baron, L.; Demangel, C.; Yelamos, J.; Brunet, E.; Deriano, L. Repair of G1 induced DNA double-strand breaks in S-G2/M by alternative NHEJ. Nat. Commun. 2020, 11, 5239. [CrossRef]

35. Zhang, Y.; Cheng, T.C.; Huang, G.; Lu, Q.; Surleac, M.D.; Mandell, J.D.; Pontarotti, P.; Petrescu, A.J.; Xu, A.; Xiong, Y.; et al. Transposon molecular domestication and the evolution of the RAG recombinase. Nature 2019, 569, 79-84. [CrossRef]

36. Zhao, B.; Watanabe, G.; Morten, M.J.; Reid, D.A.; Rothenberg, E.; Lieber, M.R. The essential elements for the noncovalent association of two DNA ends during NHEJ synapsis. Nat. Commun. 2019, 10, 3588. [CrossRef]

37. Hartlerode, A.J.; Morgan, M.J.; Wu, Y.; Buis, J.; Ferguson, D.O. Recruitment and activation of the ATM kinase in the absence of DNA-damage sensors. Nat. Struct. Mol. Biol. 2015, 22, 736-743. [CrossRef]

38. Barton, O.; Naumann, S.C.; Diemer-Biehs, R.; Kunzel, J.; Steinlage, M.; Conrad, S.; Makharashvili, N.; Wang, J.; Feng, L.; Lopez, B.S.; et al. Polo-like kinase 3 regulates CtIP during DNA double-strand break repair in G1. J. Cell Biol. 2014, 206, 877-894. [CrossRef] [PubMed] 
39. Biehs, R.; Steinlage, M.; Barton, O.; Juhasz, S.; Kunzel, J.; Spies, J.; Shibata, A.; Jeggo, P.A.; Lobrich, M. DNA Double-Strand Break Resection Occurs during Non-homologous End Joining in G1 but Is Distinct from Resection during Homologous Recombination. Mol. Cell 2017, 65, 671-684.e5. [CrossRef] [PubMed]

40. Iyama, T.; Wilson 3rd, D.M. DNA repair mechanisms in dividing and non-dividing cells. DNA Repair 2013, 12, 620-636. [CrossRef] [PubMed]

41. Pryor, J.M.; Conlin, M.P.; Carvajal-Garcia, J.; Luedeman, M.E.; Luthman, A.J.; Small, G.W.; Ramsden, D.A. Ribonucleotide incorporation enables repair of chromosome breaks by nonhomologous end joining. Science 2018, 361, 1126-1129. [CrossRef] [PubMed]

42. Roberts, S.A.; Strande, N.; Burkhalter, M.D.; Strom, C.; Havener, J.M.; Hasty, P.; Ramsden, D.A. Ku is a 5'-dRP/AP lyase that excises nucleotide damage near broken ends. Nature 2010, 464, 1214-1217. [CrossRef] [PubMed]

43. Shibata, A.; Conrad, S.; Birraux, J.; Geuting, V.; Barton, O.; Ismail, A.; Kakarougkas, A.; Meek, K.; Taucher-Scholz, G.; Lobrich, M.; et al. Factors determining DNA double-strand break repair pathway choice in G2 phase. EMBO J. 2011, 30, 1079-1092. [CrossRef] [PubMed]

44. Daley, J.M.; Wilson, T.E. Rejoining of DNA double-strand breaks as a function of overhang length. Mol. Cell Biol. 2005, 25, 896-906. [CrossRef]

45. Frank, K.M.; Sekiguchi, J.M.; Seidl, K.J.; Swat, W.; Rathbun, G.A.; Cheng, H.L.; Davidson, L.; Kangaloo, L.; Alt, F.W. Late embryonic lethality and impaired V(D)J recombination in mice lacking DNA ligase, I.V. Nature 1998, 396, 173-177. [CrossRef] [PubMed]

46. Gao, Y.; Sun, Y.; Frank, K.M.; Dikkes, P.; Fujiwara, Y.; Seidl, K.J.; Sekiguchi, J.M.; Rathbun, G.A.; Swat, W.; Wang, J.; et al. A critical role for DNA end-joining proteins in both lymphogenesis and neurogenesis. Cell 1998, 95, 891-902. [CrossRef]

47. Gu, Y.; Seidl, K.J.; Rathbun, G.A.; Zhu, C.; Manis, J.P.; van der Stoep, N.; Davidson, L.; Cheng, H.L.; Sekiguchi, J.M.; Frank, K.; et al. Growth retardation and leaky SCID phenotype of Ku70-deficient mice. Immunity 1997, 7, 653-665. [CrossRef]

48. Nussenzweig, A.; Chen, C.; da Costa Soares, V.; Sanchez, M.; Sokol, K.; Nussenzweig, M.C.; Li, G.C. Requirement for Ku80 in growth and immunoglobulin V(D)J recombination. Nature 1996, 382, 551-555. [CrossRef]

49. Rooney, S.; Sekiguchi, J.; Zhu, C.; Cheng, H.L.; Manis, J.; Whitlow, S.; DeVido, J.; Foy, D.; Chaudhuri, J.; Lombard, D.; et al. Leaky Scid phenotype associated with defective V(D)J coding end processing in Artemis-deficient mice. Mol. Cell 2002, 10, 1379-1390 [CrossRef]

50. Taccioli, G.E.; Rathbun, G.; Oltz, E.; Stamato, T.; Jeggo, P.A.; Alt, F.W. Impairment of V(D)J recombination in double-strand break repair mutants. Science 1993, 260, 207-210. [CrossRef]

51. Zhu, C.; Bogue, M.A.; Lim, D.S.; Hasty, P.; Roth, D.B. Ku86-deficient mice exhibit severe combined immunodeficiency and defective processing of V(D)J recombination intermediates. Cell 1996, 86, 379-389. [CrossRef]

52. Wang, X.S.; Lee, B.J.; Zha, S. The recent advances in non-homologous end-joining through the lens of lymphocyte development. DNA Repair 2020, 94, 102874. [CrossRef]

53. Frit, P.; Ropars, V.; Modesti, M.; Charbonnier, J.B.; Calsou, P. Plugged into the Ku-DNA hub: The NHEJ network. Prog. Biophys. Mol. Biol. 2019, 147, 62-76. [CrossRef]

54. Walker, J.R.; Corpina, R.A.; Goldberg, J. Structure of the Ku heterodimer bound to DNA and its implications for double-strand break repair. Nature 2001, 412, 607-614. [CrossRef]

55. Yoo, S.; Dynan, W.S. Geometry of a complex formed by double strand break repair proteins at a single DNA end: Recruitment of DNA-PKcs induces inward translocation of Ku protein. Nucleic Acids Res. 1999, 27, 4679-4686. [CrossRef]

56. Krasner, D.S.; Daley, J.M.; Sung, P.; Niu, H. Interplay between Ku and Replication Protein A in the Restriction of Exo1-mediated DNA Break End Resection. J. Biol. Chem. 2015, 290, 18806-18816. [CrossRef] [PubMed]

57. Oz, R.; Wang, J.L.; Guerois, R.; Goyal, G.; Kk, S.; Ropars, V.; Sharma, R.; Koca, F.; Charbonnier, J.B.; Modesti, M.; et al. Dynamics of Ku and bacterial non-homologous end-joining characterized using single DNA molecule analysis. Nucleic Acids Res. 2021, 49, $2629-2641$. [CrossRef] [PubMed]

58. Gell, D.; Jackson, S.P. Mapping of protein-protein interactions within the DNA-dependent protein kinase complex. Nucleic Acids Res. 1999, 27, 3494-3502. [CrossRef] [PubMed]

59. Singleton, B.K.; Torres-Arzayus, M.I.; Rottinghaus, S.T.; Taccioli, G.E.; Jeggo, P.A. The C terminus of Ku80 activates the DNAdependent protein kinase catalytic subunit. Mol. Cell Biol. 1999, 19, 3267-3277. [CrossRef]

60. Graham, T.G.; Walter, J.C.; Loparo, J.J. Two-Stage Synapsis of DNA Ends during Non-homologous End Joining. Mol. Cell 2016, 61, 850-858. [CrossRef]

61. Graham, T.G.W.; Carney, S.M.; Walter, J.C.; Loparo, J.J. A single XLF dimer bridges DNA ends during nonhomologous end joining. Nat. Struct. Mol. Biol. 2018, 25, 877-884. [CrossRef] [PubMed]

62. Wang, J.L.; Duboc, C.; Wu, Q.; Ochi, T.; Liang, S.; Tsutakawa, S.E.; Lees-Miller, S.P.; Nadal, M.; Tainer, J.A.; Blundell, T.L.; et al. Dissection of DNA double-strand-break repair using novel single-molecule forceps. Nat. Struct. Mol. Biol. 2018, $25,482-487$. [CrossRef] [PubMed]

63. Ochi, T.; Blackford, A.N.; Coates, J.; Jhujh, S.; Mehmood, S.; Tamura, N.; Travers, J.; Wu, Q.; Draviam, V.M.; Robinson, C.V.; et al. PAXX, a paralog of XRCC4 and XLF, interacts with Ku to promote DNA double-strand break repair. Science 2015, 347, 185-188. [CrossRef] [PubMed] 
64. Tadi, S.K.; Tellier-Lebegue, C.; Nemoz, C.; Drevet, P.; Audebert, S.; Roy, S.; Meek, K.; Charbonnier, J.B.; Modesti, M. PAXX Is an Accessory c-NHEJ Factor that Associates with Ku70 and Has Overlapping Functions with XLF. Cell Rep. 2016, 17, 541-555. [CrossRef] [PubMed]

65. Xing, M.; Yang, M.; Huo, W.; Feng, F.; Wei, L.; Jiang, W.; Ning, S.; Yan, Z.; Li, W.; Wang, Q.; et al. Interactome analysis identifies a new paralogue of XRCC4 in non-homologous end joining DNA repair pathway. Nat. Commun. 2015, 6, 6233. [CrossRef]

66. Carney, S.M.; Moreno, A.T.; Piatt, S.C.; Cisneros-Aguirre, M.; Lopezcolorado, F.W.; Stark, J.M.; Loparo, J.J. XLF acts as a flexible connector during non-homologous end joining. eLife 2020, 9, e61920. [CrossRef]

67. Grundy, G.J.; Rulten, S.L.; Arribas-Bosacoma, R.; Davidson, K.; Kozik, Z.; Oliver, A.W.; Pearl, L.H.; Caldecott, K.W. The Kubinding motif is a conserved module for recruitment and stimulation of non-homologous end-joining proteins. Nat. Commun. 2016, 7, 11242. [CrossRef]

68. Hammel, M.; Yu, Y.; Radhakrishnan, S.K.; Chokshi, C.; Tsai, M.S.; Matsumoto, Y.; Kuzdovich, M.; Remesh, S.G.; Fang, S.; Tomkinson, A.E.; et al. An Intrinsically Disordered APLF Links Ku, DNA-PKcs, and XRCC4-DNA Ligase IV in an Extended Flexible Non-homologous End Joining Complex. J. Biol. Chem. 2016, 291, 26987-27006. [CrossRef]

69. Yu, Y.; Mahaney, B.L.; Yano, K.; Ye, R.; Fang, S.; Douglas, P.; Chen, D.J.; Lees-Miller, S.P. DNA-PK and ATM phosphorylation sites in XLF/Cernunnos are not required for repair of DNA double strand breaks. DNA Repair 2008, 7, 1680-1692. [CrossRef]

70. Yu, Y.; Wang, W.; Ding, Q.; Ye, R.; Chen, D.; Merkle, D.; Schriemer, D.; Meek, K.; Lees-Miller, S.P. DNA-PK phosphorylation sites in XRCC4 are not required for survival after radiation or for V(D)J recombination. DNA Repair 2003, 2, 1239-1252. [CrossRef]

71. Normanno, D.; Negrel, A.; de Melo, A.J.; Betzi, S.; Meek, K.; Modesti, M. Mutational phospho-mimicry reveals a regulatory role for the XRCC4 and XLF C-terminal tails in modulating DNA bridging during classical non-homologous end joining. eLife 2017, 6, e22900. [CrossRef] [PubMed]

72. Andres, S.N.; Vergnes, A.; Ristic, D.; Wyman, C.; Modesti, M.; Junop, M. A human XRCC4-XLF complex bridges DNA. Nucleic Acids Res. 2012, 40, 1868-1878. [CrossRef] [PubMed]

73. Hammel, M.; Rey, M.; Yu, Y.; Mani, R.S.; Classen, S.; Liu, M.; Pique, M.E.; Fang, S.; Mahaney, B.L.; Weinfeld, M.; et al. XRCC4 protein interactions with XRCC4-like factor (XLF) create an extended grooved scaffold for DNA ligation and double strand break repair. J. Biol. Chem. 2011, 286, 32638-32650. [CrossRef] [PubMed]

74. Hammel, M.; Yu, Y.; Fang, S.; Lees-Miller, S.P.; Tainer, J.A. XLF regulates filament architecture of the XRCC4.ligase IV complex. Structure 2010, 18, 1431-1442. [CrossRef]

75. Mahaney, B.L.; Hammel, M.; Meek, K.; Tainer, J.A.; Lees-Miller, S.P. XRCC4 and XLF form long helical protein filaments suitable for DNA end protection and alignment to facilitate DNA double strand break repair. BioChem. Cell Biol. 2013, 91, 31-41. [CrossRef]

76. Ropars, V.; Drevet, P.; Legrand, P.; Baconnais, S.; Amram, J.; Faure, G.; Marquez, J.A.; Pietrement, O.; Guerois, R.; Callebaut, I.; et al. Structural characterization of filaments formed by human Xrcc4-Cernunnos/XLF complex involved in nonhomologous DNA end-joining. Proc. Natl. Acad. Sci. USA 2011, 108, 12663-12668. [CrossRef]

77. Reid, D.A.; Keegan, S.; Leo-Macias, A.; Watanabe, G.; Strande, N.T.; Chang, H.H.; Oksuz, B.A.; Fenyo, D.; Lieber, M.R.; Ramsden, D.A.; et al. Organization and dynamics of the nonhomologous end-joining machinery during DNA double-strand break repair. Proc. Natl. Acad. Sci. USA 2015, 112, E2575-E2584. [CrossRef]

78. Brouwer, I.; Sitters, G.; Candelli, A.; Heerema, S.J.; Heller, I.; de Melo, A.J.; Zhang, H.; Normanno, D.; Modesti, M.; Peterman, E.J.; et al. Sliding sleeves of XRCC4-XLF bridge DNA and connect fragments of broken DNA. Nature 2016, 535, 566-569. [CrossRef]

79. Li, W.; Bai, X.; Li, J.; Zhao, Y.; Liu, J.; Zhao, H.; Liu, L.; Ding, M.; Wang, Q.; Shi, F.Y.; et al. The nucleoskeleton protein IFFO1 immobilizes broken DNA and suppresses chromosome translocation during tumorigenesis. Nat. Cell Biol. 2019, 21, 1273-1285. [CrossRef]

80. Rober, R.A.; Weber, K.; Osborn, M. Differential timing of nuclear lamin A/C expression in the various organs of the mouse embryo and the young animal: A developmental study. Development 1989, 105, 365-378. [CrossRef]

81. Bell, E.S.; Lammerding, J. Causes and consequences of nuclear envelope alterations in tumour progression. Eur. J. Cell Biol. 2016, 95, 449-464. [CrossRef]

82. Lucas, J.S.; Zhang, Y.; Dudko, O.K.; Murre, C. 3D trajectories adopted by coding and regulatory DNA elements: First-passage times for genomic interactions. Cell 2014, 158, 339-352. [CrossRef]

83. Setiaputra, D.; Durocher, D. Shieldin-The protector of DNA ends. EMBO Rep. 2019, 20, e47560. [CrossRef]

84. Zhao, B.; Rothenberg, E.; Ramsden, D.A.; Lieber, M.R. The molecular basis and disease relevance of non-homologous DNA end joining. Nat. Rev. Mol. Cell Biol. 2020, 21, 765-781. [CrossRef]

85. Bredemeyer, A.L.; Sharma, G.G.; Huang, C.Y.; Helmink, B.A.; Walker, L.M.; Khor, K.C.; Nuskey, B.; Sullivan, K.E.; Pandita, T.K.; Bassing, C.H.; et al. ATM stabilizes DNA double-strand-break complexes during V(D)J recombination. Nature 2006, 442, 466-470. [CrossRef] [PubMed]

86. Callen, E.; Jankovic, M.; Difilippantonio, S.; Daniel, J.A.; Chen, H.T.; Celeste, A.; Pellegrini, M.; McBride, K.; Wangsa, D.; Bredemeyer, A.L.; et al. ATM prevents the persistence and propagation of chromosome breaks in lymphocytes. Cell 2007, 130, 63-75. [CrossRef] [PubMed]

87. Balasubramanian, N.; Bai, P.; Buchek, G.; Korza, G.; Weller, S.K. Physical interaction between the herpes simplex virus type 1 exonuclease, UL12, and the DNA double-strand break-sensing MRN complex. J. Virol. 2010, 84, 12504-12514. [CrossRef] [PubMed] 
88. Haince, J.F.; McDonald, D.; Rodrigue, A.; Dery, U.; Masson, J.Y.; Hendzel, M.J.; Poirier, G.G. PARP1-dependent kinetics of recruitment of MRE11 and NBS1 proteins to multiple DNA damage sites. J. Biol. Chem. 2008, 283, 1197-1208. [CrossRef]

89. Wang, Q.; Goldstein, M.; Alexander, P.; Wakeman, T.P.; Sun, T.; Feng, J.; Lou, Z.; Kastan, M.B.; Wang, X.F. Rad17 recruits the MRE11-RAD50-NBS1 complex to regulate the cellular response to DNA double-strand breaks. EMBO J. 2014, 33, 862-877. [CrossRef] [PubMed]

90. Hung, P.J.; Johnson, B.; Chen, B.R.; Byrum, A.K.; Bredemeyer, A.L.; Yewdell, W.T.; Johnson, T.E.; Lee, B.J.; Deivasigamani, S.; Hindi, I.; et al. MRI Is a DNA Damage Response Adaptor during Classical Non-homologous End Joining. Mol. Cell 2018, 71, 332-342.e8. [CrossRef] [PubMed]

91. Arnoult, N.; Correia, A.; Ma, J.; Merlo, A.; Garcia-Gomez, S.; Maric, M.; Tognetti, M.; Benner, C.W.; Boulton, S.J.; Saghatelian, A.; et al. Regulation of DNA repair pathway choice in S and G2 phases by the NHEJ inhibitor CYREN. Nature 2017, 549, 548-552. [CrossRef]

92. Kumar, V.; Alt, F.W.; Frock, R.L. PAXX and XLF DNA repair factors are functionally redundant in joining DNA breaks in a G1-arrested progenitor B-cell line. Proc. Natl. Acad. Sci. USA 2016, 113, 10619-10624. [CrossRef]

93. Musilli, S.; Abramowski, V.; Roch, B.; de Villartay, J.P. An in vivo study of the impact of deficiency in the DNA repair proteins PAXX and XLF on development and maturation of the hemolymphoid system. J. Biol. Chem. 2020, 295, 2398-2406. [CrossRef]

94. Francica, P.; Mutlu, M.; Blomen, V.A.; Oliveira, C.; Nowicka, Z.; Trenner, A.; Gerhards, N.M.; Bouwman, P.; Stickel, E.; Hekkelman, M.L.; et al. Functional Radiogenetic Profiling Implicates ERCC6L2 in Non-homologous End Joining. Cell Rep. 2020, 32, 108068. [CrossRef]

95. Liu, X.; Liu, T.; Shang, Y.; Dai, P.; Zhang, W.; Lee, B.J.; Huang, M.; Yang, D.; Wu, Q.; Liu, L.D.; et al. ERCC6L2 promotes DNA orientation-specific recombination in mammalian cells. Cell Res. 2020, 30, 732-744. [CrossRef]

96. Olivieri, M.; Cho, T.; Alvarez-Quilon, A.; Li, K.; Schellenberg, M.J.; Zimmermann, M.; Hustedt, N.; Rossi, S.E.; Adam, S.; Melo, H.; et al. A Genetic Map of the Response to DNA Damage in Human Cells. Cell 2020, 182, 481-496.e21. [CrossRef]

97. Zhang, S.; Pondarre, C.; Pennarun, G.; Labussiere-Wallet, H.; Vera, G.; France, B.; Chansel, M.; Rouvet, I.; Revy, P.; Lopez, B.; et al. A nonsense mutation in the DNA repair factor Hebo causes mild bone marrow failure and microcephaly. J. Exp. Med. 2016, 213, 1011-1028. [CrossRef] [PubMed]

98. Tummala, H.; Dokal, A.D.; Walne, A.; Ellison, A.; Cardoso, S.; Amirthasigamanipillai, S.; Kirwan, M.; Browne, I.; Sidhu, J.K.; Rajeeve, V; et al. Genome instability is a consequence of transcription deficiency in patients with bone marrow failure harboring biallelic ERCC6L2 variants. Proc. Natl. Acad. Sci. USA 2018, 115, 7777-7782. [CrossRef] [PubMed]

99. Aravind, L.; Walker, D.R.; Koonin, E.V. Conserved domains in DNA repair proteins and evolution of repair systems. Nucleic Acids Res. 1999, 27, 1223-1242. [CrossRef] [PubMed]

100. Chen, X.; Tomkinson, A.E. Yeast Nej1 is a key participant in the initial end binding and final ligation steps of nonhomologous end joining. J. Biol. Chem. 2011, 286, 4931-4940. [CrossRef] [PubMed]

101. Paull, T.T. 20 Years of Mre11 Biology: No End in Sight. Mol. Cell 2018, 71, 419-427. [CrossRef]

102. Myler, L.R.; Gallardo, I.F.; Soniat, M.M.; Deshpande, R.A.; Gonzalez, X.B.; Kim, Y.; Paull, T.T.; Finkelstein, I.J. Single-Molecule Imaging Reveals How Mre11-Rad50-Nbs1 Initiates DNA Break Repair. Mol. Cell 2017, 67, 891-898.e4. [CrossRef]

103. Bian, L.; Meng, Y.; Zhang, M.; Li, D. MRE11-RAD50-NBS1 complex alterations and DNA damage response: Implications for cancer treatment. Mol. Cancer 2019, 18, 169. [CrossRef]

104. Syed, A.; Tainer, J.A. The MRE11-RAD50-NBS1 Complex Conducts the Orchestration of Damage Signaling and Outcomes to Stress in DNA Replication and Repair. Ann. Rev. BioChem. 2018, 87, 263-294. [CrossRef] [PubMed]

105. Tatebe, H.; Lim, C.T.; Konno, H.; Shiozaki, K.; Shinohara, A.; Uchihashi, T.; Furukohri, A. Rad50 zinc hook functions as a constitutive dimerization module interchangeable with SMC hinge. Nat. Commun. 2020, 11, 370. [CrossRef]

106. De Jager, M.; van Noort, J.; van Gent, D.C.; Dekker, C.; Kanaar, R.; Wyman, C. Human Rad50/Mre11 is a flexible complex that can tether DNA ends. Mol. Cell 2001, 8, 1129-1135. [CrossRef]

107. Hohl, M.; Kwon, Y.; Galvan, S.M.; Xue, X.; Tous, C.; Aguilera, A.; Sung, P.; Petrini, J.H. The Rad50 coiled-coil domain is indispensable for Mre11 complex functions. Nat. Struct. Mol. Biol. 2011, 18, 1124-1131. [CrossRef] [PubMed]

108. Moreno-Herrero, F.; de Jager, M.; Dekker, N.H.; Kanaar, R.; Wyman, C.; Dekker, C. Mesoscale conformational changes in the DNA-repair complex Rad50/Mre11/Nbs1 upon binding DNA. Nature 2005, 437, 440-443. [CrossRef] [PubMed]

109. Castaneda-Zegarra, S.; Fernandez-Berrocal, M.; Tkachov, M.; Yao, R.; Upfold, N.L.E.; Oksenych, V. Genetic interaction between the non-homologous end-joining factors during B and T lymphocyte development: In vivo mouse models. Scand. J. Immunol. 2020, 92, e12936. [CrossRef]

110. Lescale, C.; Lenden Hasse, H.; Blackford, A.N.; Balmus, G.; Bianchi, J.J.; Yu, W.; Bacoccina, L.; Jarade, A.; Clouin, C.; Sivapalan, R.; et al. Specific Roles of XRCC4 Paralogs PAXX and XLF during V(D)J Recombination. Cell Rep. 2016, 16, 2967-2979. [CrossRef]

111. Liu, X.; Shao, Z.; Jiang, W.; Lee, B.J.; Zha, S. PAXX promotes KU accumulation at DNA breaks and is essential for end-joining in XLF-deficient mice. Nat. Commun. 2017, 8, 13816. [CrossRef]

112. Oksenych, V.; Kumar, V.; Liu, X.; Guo, C.; Schwer, B.; Zha, S.; Alt, F.W. Functional redundancy between the XLF and DNA-PKcs DNA repair factors in V(D)J recombination and nonhomologous DNA end joining. Proc. Natl. Acad. Sci. USA 2013, 110, $2234-2239$. [CrossRef]

113. Zha, S.; Guo, C.; Boboila, C.; Oksenych, V.; Cheng, H.L.; Zhang, Y.; Wesemann, D.R.; Yuen, G.; Patel, H.; Goff, P.H.; et al. ATM damage response and XLF repair factor are functionally redundant in joining DNA breaks. Nature 2011, 469, 250-254. [CrossRef] 
114. Arnould, C.; Rocher, V.; Finoux, A.L.; Clouaire, T.; Li, K.; Zhou, F.; Caron, P.; Mangeot, P.E.; Ricci, E.P.; Mourad, R.; et al. Loop extrusion as a mechanism for formation of DNA damage repair foci. Nature 2021, 590, 660-665. [CrossRef]

115. Li, K.; Bronk, G.; Kondev, J.; Haber, J.E. Yeast ATM and ATR kinases use different mechanisms to spread histone H2A phosphorylation around a DNA double-strand break. Proc. Natl. Acad. Sci. USA 2020, 117, 21354-21363. [CrossRef]

116. Blackford, A.N.; Jackson, S.P. ATM, ATR, and DNA-PK: The Trinity at the Heart of the DNA Damage Response. Mol. Cell 2017, 66, 801-817. [CrossRef]

117. Clouaire, T.; Legube, G. A Snapshot on the Cis Chromatin Response to DNA Double-Strand Breaks. Trends Genet. 2019, 35, 330-345. [CrossRef]

118. Hauer, M.H.; Gasser, S.M. Chromatin and nucleosome dynamics in DNA damage and repair. Genes Dev. 2017, 31, $2204-2221$. [CrossRef] [PubMed]

119. Orthwein, A.; Noordermeer, S.M.; Wilson, M.D.; Landry, S.; Enchev, R.I.; Sherker, A.; Munro, M.; Pinder, J.; Salsman, J.; Dellaire, G.; et al. A mechanism for the suppression of homologous recombination in G1 cells. Nature 2015, 528, 422-426. [CrossRef] [PubMed]

120. Deshpande, R.A.; Williams, G.J.; Limbo, O.; Williams, R.S.; Kuhnlein, J.; Lee, J.H.; Classen, S.; Guenther, G.; Russell, P.; Tainer, J.A.; et al. ATP-driven Rad50 conformations regulate DNA tethering, end resection, and ATM checkpoint signaling. EMBO J. 2014, 33, 482-500. [CrossRef] [PubMed]

121. Lammens, K.; Bemeleit, D.J.; Mockel, C.; Clausing, E.; Schele, A.; Hartung, S.; Schiller, C.B.; Lucas, M.; Angermuller, C.; Soding, J.; et al. The Mre11:Rad50 structure shows an ATP-dependent molecular clamp in DNA double-strand break repair. Cell 2011, 145, 54-66. [CrossRef]

122. Lim, H.S.; Kim, J.S.; Park, Y.B.; Gwon, G.H.; Cho, Y. Crystal structure of the Mre11-Rad50-ATPgammaS complex: Understanding the interplay between Mre11 and Rad50. Genes Dev. 2011, 25, 1091-1104. [CrossRef] [PubMed]

123. Williams, G.J.; Williams, R.S.; Williams, J.S.; Moncalian, G.; Arvai, A.S.; Limbo, O.; Guenther, G.; SilDas, S.; Hammel, M.; Russell, P.; et al. ABC ATPase signature helices in Rad50 link nucleotide state to Mre11 interface for DNA repair. Nat. Struct. Mol. Biol. 2011, 18, 423-431. [CrossRef] [PubMed]

124. Paull, T.T.; Gellert, M. The $3^{\prime}$ to $5^{\prime}$ exonuclease activity of Mre 11 facilitates repair of DNA double-strand breaks. Mol. Cell 1998, 1 , 969-979. [CrossRef]

125. Shibata, A.; Moiani, D.; Arvai, A.S.; Perry, J.; Harding, S.M.; Genois, M.M.; Maity, R.; van Rossum-Fikkert, S.; Kertokalio, A.; Romoli, F.; et al. DNA double-strand break repair pathway choice is directed by distinct MRE11 nuclease activities. Mol. Cell 2014, 53, 7-18. [CrossRef]

126. Lloyd, J.; Chapman, J.R.; Clapperton, J.A.; Haire, L.F.; Hartsuiker, E.; Li, J.; Carr, A.M.; Jackson, S.P.; Smerdon, S.J. A supramodular FHA/BRCT-repeat architecture mediates Nbs1 adaptor function in response to DNA damage. Cell 2009, 139, 100-111. [CrossRef]

127. Sartori, A.A.; Lukas, C.; Coates, J.; Mistrik, M.; Fu, S.; Bartek, J.; Baer, R.; Lukas, J.; Jackson, S.P. Human CtIP promotes DNA end resection. Nature 2007, 450, 509-514. [CrossRef] [PubMed]

128. Williams, R.S.; Dodson, G.E.; Limbo, O.; Yamada, Y.; Williams, J.S.; Guenther, G.; Classen, S.; Glover, J.N.; Iwasaki, H.; Russell, P.; et al. Nbs1 flexibly tethers Ctp1 and Mre11-Rad50 to coordinate DNA double-strand break processing and repair. Cell 2009, 139, 87-99. [CrossRef]

129. Deshpande, R.A.; Lee, J.H.; Arora, S.; Paull, T.T. Nbs1 Converts the Human Mre11/Rad50 Nuclease Complex into an Endo/Exonuclease Machine Specific for Protein-DNA Adducts. Mol. Cell 2016, 64, 593-606. [CrossRef] [PubMed]

130. Aparicio, T.; Baer, R.; Gottesman, M.; Gautier, J. MRN, CtIP, and BRCA1 mediate repair of topoisomerase II-DNA adducts. J. Cell Biol. 2016, 212, 399-408. [CrossRef] [PubMed]

131. Huertas, P.; Jackson, S.P. Human CtIP mediates cell cycle control of DNA end resection and double strand break repair. J. Biol. Chem. 2009, 284, 9558-9565. [CrossRef] [PubMed]

132. Peterson, S.E.; Li, Y.; Wu-Baer, F.; Chait, B.T.; Baer, R.; Yan, H.; Gottesman, M.E.; Gautier, J. Activation of DSB processing requires phosphorylation of CtIP by ATR. Mol. Cell 2013, 49, 657-667. [CrossRef] [PubMed]

133. Helmink, B.A.; Bredemeyer, A.L.; Lee, B.S.; Huang, C.Y.; Sharma, G.G.; Walker, L.M.; Bednarski, J.J.; Lee, W.L.; Pandita, T.K.; Bassing, C.H.; et al. MRN complex function in the repair of chromosomal Rag-mediated DNA double-strand breaks. J. Exp. Med. 2009, 206, 669-679. [CrossRef]

134. Lee, G.S.; Neiditch, M.B.; Salus, S.S.; Roth, D.B. RAG proteins shepherd double-strand breaks to a specific pathway, suppressing error-prone repair, but RAG nicking initiates homologous recombination. Cell 2004, 117, 171-184. [CrossRef]

135. Mages, C.F.; Wintsche, A.; Bernhart, S.H.; Muller, G.A. The DREAM complex through its subunit Lin37 cooperates with Rb to initiate quiescence. eLife 2019, 6, e26876. [CrossRef]

136. Gorgoulis, V.; Adams, P.D.; Alimonti, A.; Bennett, D.C.; Bischof, O.; Bishop, C.; Campisi, J.; Collado, M.; Evangelou, K.; Ferbeyre, G.; et al. Cellular Senescence: Defining a Path Forward. Cell 2019, 179, 813-827. [CrossRef] [PubMed]

137. Lecot, P.; Alimirah, F.; Desprez, P.Y.; Campisi, J.; Wiley, C. Context-dependent effects of cellular senescence in cancer development. Br. J. Cancer 2016, 114, 1180-1184. [CrossRef] [PubMed]

138. Von Zglinicki, T.; Wan, T.; Miwa, S. Senescence in Post-Mitotic Cells: A Driver of Aging? Antioxid. Redox Signal. 2021, $34,308-323$. [CrossRef]

139. Zhou, Y.; Lee, J.H.; Jiang, W.; Crowe, J.L.; Zha, S.; Paull, T.T. Regulation of the DNA Damage Response by DNA-PKcs Inhibitory Phosphorylation of ATM. Mol. Cell 2017, 65, 91-104. [CrossRef] 
140. Jiang, W.; Crowe, J.L.; Liu, X.; Nakajima, S.; Wang, Y.; Li, C.; Lee, B.J.; Dubois, R.L.; Liu, C.; Yu, X.; et al. Differential phosphorylation of DNA-PKcs regulates the interplay between end-processing and end-ligation during nonhomologous endjoining. Mol. Cell 2015, 58, 172-185. [CrossRef]

141. Weterings, E.; Verkaik, N.S.; Keijzers, G.; Florea, B.I.; Wang, S.Y.; Ortega, L.G.; Uematsu, N.; Chen, D.J.; van Gent, D.C. The Ku80 carboxy terminus stimulates joining and artemis-mediated processing of DNA ends. Mol. Cell Biol. 2009, 29, 1134-1142. [CrossRef]

142. Ma, Y.; Pannicke, U.; Schwarz, K.; Lieber, M.R. Hairpin opening and overhang processing by an Artemis/DNA-dependent protein kinase complex in nonhomologous end joining and V(D)J recombination. Cell 2002, 108, 781-794. [CrossRef]

143. Chang, H.H.; Watanabe, G.; Lieber, M.R. Unifying the DNA end-processing roles of the artemis nuclease: Ku-dependent artemis resection at blunt DNA ends. J. Biol. Chem. 2015, 290, 24036-24050. [CrossRef]

144. Meek, K. Activation of DNA-PK by hairpinned DNA ends reveals a stepwise mechanism of kinase activation. Nucleic Acids Res. 2020, 48, 9098-9108. [CrossRef] [PubMed]

145. Nemoz, C.; Ropars, V.; Frit, P.; Gontier, A.; Drevet, P.; Yu, J.; Guerois, R.; Pitois, A.; Comte, A.; Delteil, C.; et al. XLF and APLF bind Ku80 at two remote sites to ensure DNA repair by non-homologous end joining. Nat. Struct. Mol. Biol. 2018, 25, 971-980. [CrossRef] [PubMed]

146. Menolfi, D.; Zha, S. ATM, ATR and DNA-PKcs kinases-the lessons from the mouse models: Inhibition not equal deletion. Cell Biosci. 2020, 10, 8. [CrossRef] [PubMed]

147. Lee, K.J.; Saha, J.; Sun, J.; Fattah, K.R.; Wang, S.C.; Jakob, B.; Chi, L.; Wang, S.Y.; Taucher-Scholz, G.; Davis, A.J.; et al. Phosphorylation of Ku dictates DNA double-strand break (DSB) repair pathway choice in S phase. Nucleic Acids Res. 2016, 44, 1732-1745. [CrossRef]

148. Ishida, N.; Nakagawa, T.; Iemura, S.I.; Yasui, A.; Shima, H.; Katoh, Y.; Nagasawa, Y.; Natsume, T.; Igarashi, K.; Nakayama, K. Ubiquitylation of Ku80 by RNF126 Promotes Completion of Nonhomologous End Joining-Mediated DNA Repair. Mol. Cell Biol. 2017, 37, e00347-16. [CrossRef] [PubMed]

149. Feng, L.; Chen, J. The E3 ligase RNF8 regulates KU80 removal and NHEJ repair. Nat. Struct. Mol. Biol. 2012, 19, 201-206. [CrossRef]

150. Postow, L.; Ghenoiu, C.; Woo, E.M.; Krutchinsky, A.N.; Chait, B.T.; Funabiki, H. Ku80 removal from DNA through double strand break-induced ubiquitylation. J. Cell Biol. 2008, 182, 467-479. [CrossRef]

151. Tsai, L.J.; Lopezcolorado, F.W.; Bhargava, R.; Mendez-Dorantes, C.; Jahanshir, E.; Stark, J.M. RNF8 has both KU-dependent and independent roles in chromosomal break repair. Nucleic Acids Res. 2020, 48, 6032-6052. [CrossRef]

152. Brown, J.S.; Lukashchuk, N.; Sczaniecka-Clift, M.; Britton, S.; le Sage, C.; Calsou, P.; Beli, P.; Galanty, Y.; Jackson, S.P. Neddylation promotes ubiquitylation and release of Ku from DNA-damage sites. Cell Rep. 2015, 11, 704-714. [CrossRef]

153. Ismail, I.H.; Gagne, J.P.; Genois, M.M.; Strickfaden, H.; McDonald, D.; Xu, Z.; Poirier, G.G.; Masson, J.Y.; Hendzel, M.J. The RNF138 E3 ligase displaces Ku to promote DNA end resection and regulate DNA repair pathway choice. Nat. Cell Biol. 2015, 17, 1446-1457. [CrossRef]

154. Schmidt, C.K.; Galanty, Y.; Sczaniecka-Clift, M.; Coates, J.; Jhujh, S.; Demir, M.; Cornwell, M.; Beli, P.; Jackson, S.P. Systematic E2 screening reveals a UBE2D-RNF138-CtIP axis promoting DNA repair. Nat. Cell Biol. 2015, 17, 1458-1470. [CrossRef]

155. Van den Boom, J.; Wolf, M.; Weimann, L.; Schulze, N.; Li, F.; Kaschani, F.; Riemer, A.; Zierhut, C.; Kaiser, M.; Iliakis, G.; et al. VCP/p97 Extracts Sterically Trapped Ku70/80 Rings from DNA in Double-Strand Break Repair. Mol. Cell 2016, 64, 189-198. [CrossRef]

156. Lu, R.; Zhang, H.; Jiang, Y.N.; Wang, Z.Q.; Sun, L.; Zhou, Z.W. Post-Translational Modification of MRE11: Its Implication in DDR and Diseases. Genes 2021, 12, 1158. [CrossRef] [PubMed]

157. Kilgas, S.; Singh, A.N.; Paillas, S.; Then, C.K.; Torrecilla, I.; Nicholson, J.; Browning, L.; Vendrell, I.; Konietzny, R.; Kessler, B.M.; et al. p97/VCP inhibition causes excessive MRE11-dependent DNA end resection promoting cell killing after ionizing radiation. Cell Rep. 2021, 35, 109153. [CrossRef]

158. Audebert, M.; Salles, B.; Calsou, P. Involvement of poly(ADP-ribose) polymerase-1 and XRCC1/DNA ligase III in an alternative route for DNA double-strand breaks rejoining. J. Biol. Chem. 2004, 279, 55117-55126. [CrossRef] [PubMed]

159. Bennardo, N.; Cheng, A.; Huang, N.; Stark, J.M. Alternative-NHEJ is a mechanistically distinct pathway of mammalian chromosome break repair. PLoS Genet. 2008, 4, e1000110. [CrossRef] [PubMed]

160. Boboila, C.; Jankovic, M.; Yan, C.T.; Wang, J.H.; Wesemann, D.R.; Zhang, T.; Fazeli, A.; Feldman, L.; Nussenzweig, A.; Nussenzweig, M.; et al. Alternative end-joining catalyzes robust IgH locus deletions and translocations in the combined absence of ligase 4 and Ku70. Proc. Natl. Acad. Sci. USA 2010, 107, 3034-3039. [CrossRef]

161. Boboila, C.; Oksenych, V.; Gostissa, M.; Wang, J.H.; Zha, S.; Zhang, Y.; Chai, H.; Lee, C.S.; Jankovic, M.; Saez, L.M.; et al. Robust chromosomal DNA repair via alternative end-joining in the absence of X-ray repair cross-complementing protein 1 (XRCC1). Proc. Natl. Acad. Sci. USA 2012, 109, 2473-2478. [CrossRef]

162. Boboila, C.; Yan, C.; Wesemann, D.R.; Jankovic, M.; Wang, J.H.; Manis, J.; Nussenzweig, A.; Nussenzweig, M.; Alt, F.W. Alternative end-joining catalyzes class switch recombination in the absence of both Ku70 and DNA ligase 4. J. Exp. Med. 2010, 207, 417-427. [CrossRef]

163. Ceccaldi, R.; Liu, J.C.; Amunugama, R.; Hajdu, I.; Primack, B.; Petalcorin, M.I.; O'Connor, K.W.; Konstantinopoulos, P.A.; Elledge, S.J.; Boulton, S.J.; et al. Homologous-recombination-deficient tumours are dependent on Poltheta-mediated repair. Nature 2015, 518, 258-262. [CrossRef] 
164. Haber, J.E. Alternative endings. Proc. Natl. Acad. Sci. USA 2008, 105, 405-406. [CrossRef]

165. Howard, S.M.; Yanez, D.A.; Stark, J.M. DNA damage response factors from diverse pathways, including DNA crosslink repair, mediate alternative end joining. PLoS Genet. 2015, 11, e1004943. [CrossRef] [PubMed]

166. Kang, Y.J.; Yan, C.T. Regulation of DNA repair in the absence of classical non-homologous end joining. DNA Repair 2018, 68, 34-40. [CrossRef] [PubMed]

167. Liu, Q.; Ma, L.; Jones, T.; Palomero, L.; Pujana, M.A.; Martinez-Ruiz, H.; Ha, P.K.; Murnane, J.; Cuartas, I.; Seoane, J.; et al. Subjugation of TGFbeta Signaling by Human Papilloma Virus in Head and Neck Squamous Cell Carcinoma Shifts DNA Repair from Homologous Recombination to Alternative End Joining. Clin. Cancer Res. 2018, 24, 6001-6014. [CrossRef] [PubMed]

168. Mansour, W.Y.; Borgmann, K.; Petersen, C.; Dikomey, E.; Dahm-Daphi, J. The absence of Ku but not defects in classical nonhomologous end-joining is required to trigger PARP1-dependent end-joining. DNA Repair 2013, 12, 1134-1142. [CrossRef] [PubMed]

169. Masani, S.; Han, L.; Meek, K.; Yu, K. Redundant function of DNA ligase 1 and 3 in alternative end-joining during immunoglobulin class switch recombination. Proc. Natl. Acad. Sci. USA 2016, 113, 1261-1266. [CrossRef]

170. Mateos-Gomez, P.A.; Gong, F.; Nair, N.; Miller, K.M.; Lazzerini-Denchi, E.; Sfeir, A. Mammalian polymerase theta promotes alternative NHEJ and suppresses recombination. Nature 2015, 518, 254-257. [CrossRef] [PubMed]

171. Shukla, V.; Halabelian, L.; Balagere, S.; Samaniego-Castruita, D.; Feldman, D.E.; Arrowsmith, C.H.; Rao, A.; Aravind, L. HMCES Functions in the Alternative End-Joining Pathway of the DNA DSB Repair during Class Switch Recombination in B Cells. Mol. Cell 2020, 77, 1154. [CrossRef]

172. Simsek, D.; Brunet, E.; Wong, S.Y.; Katyal, S.; Gao, Y.; McKinnon, P.J.; Lou, J.; Zhang, L.; Li, J.; Rebar, E.J.; et al. DNA ligase III promotes alternative nonhomologous end-joining during chromosomal translocation formation. PLoS Genet. 2011, 7, e1002080. [CrossRef] [PubMed]

173. Wang, H.; Perrault, A.R.; Takeda, Y.; Qin, W.; Wang, H.; Iliakis, G. Biochemical evidence for Ku-independent backup pathways of NHEJ. Nucleic Acids Res. 2003, 31, 5377-5388. [CrossRef] [PubMed]

174. Wang, M.; Wu, W.; Wu, W.; Rosidi, B.; Zhang, L.; Wang, H.; Iliakis, G. PARP-1 and Ku compete for repair of DNA double strand breaks by distinct NHEJ pathways. Nucleic Acids Res. 2006, 34, 6170-6182. [CrossRef] [PubMed]

175. Wang, X.S.; Zhao, J.; Wu-Baer, F.; Shao, Z.; Lee, B.J.; Cupo, O.M.; Rabadan, R.; Gautier, J.; Baer, R.; Zha, S. CtIP-mediated DNA resection is dispensable for IgH class switch recombination by alternative end-joining. Proc. Natl. Acad. Sci. USA 2020, 117, 25700-25711. [CrossRef] [PubMed]

176. Wyatt, D.W.; Feng, W.; Conlin, M.P.; Yousefzadeh, M.J.; Roberts, S.A.; Mieczkowski, P.; Wood, R.D.; Gupta, G.P.; Ramsden, D. A Essential Roles for Polymerase theta-Mediated End Joining in the Repair of Chromosome Breaks. Mol. Cell 2016, 63, 662-673. [CrossRef]

177. Xie, A.; Kwok, A.; Scully, R. Role of mammalian Mre11 in classical and alternative nonhomologous end joining. Nat. Struct. Mol. Biol. 2009, 16, 814-818. [CrossRef]

178. Xing, M.; Bjoras, M.; Daniel, J.A.; Alt, F.W.; Oksenych, V. Synthetic lethality between murine DNA repair factors XLF and DNA-PKcs is rescued by inactivation of Ku70. DNA Repair 2017, 57, 133-138. [CrossRef] [PubMed]

179. Xiong, X.; Du, Z.; Wang, Y.; Feng, Z.; Fan, P.; Yan, C.; Willers, H.; Zhang, J. 53BP1 promotes microhomology-mediated end-joining in G1-phase cells. Nucleic Acids Res. 2015, 43, 1659-1670. [CrossRef]

180. Yamaguchi-Iwai, Y.; Sonoda, E.; Sasaki, M.S.; Morrison, C.; Haraguchi, T.; Hiraoka, Y.; Yamashita, Y.M.; Yagi, T.; Takata, M.; Price, C.; et al. Mre11 is essential for the maintenance of chromosomal DNA in vertebrate cells. EMBO J. 1999, 18, 6619-6629. [CrossRef] [PubMed]

181. Yan, C.T.; Boboila, C.; Souza, E.K.; Franco, S.; Hickernell, T.R.; Murphy, M.; Gumaste, S.; Geyer, M.; Zarrin, A.A.; Manis, J.P.; et al. IgH class switching and translocations use a robust non-classical end-joining pathway. Nature 2007, 449, 478-482. [CrossRef] [PubMed]

182. Yousefzadeh, M.J.; Wyatt, D.W.; Takata, K.; Mu, Y.X.; Hensley, S.C.; Tomida, J.; Bylund, G.O.; Doublie, S.; Johansson, E.; Ramsden, D.A.; et al. Mechanism of Suppression of Chromosomal Instability by DNA Polymerase POLQ. PLoS Genet. 2014, 10, e1004654. [CrossRef] [PubMed]

183. Yuan, Y.; Britton, S.; Delteil, C.; Coates, J.; Jackson, S.P.; Barboule, N.; Frit, P.; Calsou, P. Single-stranded DNA oligomers stimulate error-prone alternative repair of DNA double-strand breaks through hijacking Ku protein. Nucleic Acids Res. 2015, 43, 10264-10276. [CrossRef] [PubMed]

184. Zan, H.; Tat, C.; Qiu, Z.; Taylor, J.R.; Guerrero, J.A.; Shen, T.; Casali, P. Rad52 competes with Ku70/Ku86 for binding to S-region DSB ends to modulate antibody class-switch DNA recombination. Nat. Commun. 2017, 8, 14244. [CrossRef] [PubMed]

185. Zhang, Y.; Jasin, M. An essential role for CtIP in chromosomal translocation formation through an alternative end-joining pathway. Nat. Struct. Mol. Biol. 2011, 18, 80-84. [CrossRef]

186. Zhu, C.; Mills, K.D.; Ferguson, D.O.; Lee, C.; Manis, J.; Fleming, J.; Gao, Y.; Morton, C.C.; Alt, F.W. Unrepaired DNA breaks in p53-deficient cells lead to oncogenic gene amplification subsequent to translocations. Cell 2002, 109, 811-821. [CrossRef]

187. Chandramouly, G.; Zhao, J.; McDevitt, S.; Rusanov, T.; Hoang, T.; Borisonnik, N.; Treddinick, T.; Lopezcolorado, F.W.; Kent, T.; Siddique, L.A.; et al. Poltheta reverse transcribes RNA and promotes RNA-templated DNA repair. Sci. Adv. 2021, 7, eabf1771. [CrossRef] 
188. Schrempf, A.; Slyskova, J.; Loizou, J.I. Targeting the DNA Repair Enzyme Polymerase theta in Cancer Therapy. Trends Cancer 2021, 7, 98-111. [CrossRef]

189. Britton, S.; Chanut, P.; Delteil, C.; Barboule, N.; Frit, P.; Calsou, P. ATM antagonizes NHEJ proteins assembly and DNA-ends synapsis at single-ended DNA double strand breaks. Nucleic Acids Res. 2020, 48, 9710-9723. [CrossRef]

190. Willis, N.A.; Panday, A.; Duffey, E.E.; Scully, R. Rad51 recruitment and exclusion of non-homologous end joining during homologous recombination at a Tus/Ter mammalian replication fork barrier. PLoS Genet. 2018, 14, e1007486. [CrossRef]

191. Moser, J.; Kool, H.; Giakzidis, I.; Caldecott, K.; Mullenders, L.H.; Fousteri, M.I. Sealing of chromosomal DNA nicks during nucleotide excision repair requires XRCC1 and DNA ligase III alpha in a cell-cycle-specific manner. Mol. Cell 2007, 27, 311-323. [CrossRef]

192. Arakawa, H.; Bednar, T.; Wang, M.; Paul, K.; Mladenov, E.; Bencsik-Theilen, A.A.; Iliakis, G. Functional redundancy between DNA ligases I and III in DNA replication in vertebrate cells. Nucleic Acids Res. 2012, 40, 2599-2610. [CrossRef] [PubMed]

193. Hanzlikova, H.; Kalasova, I.; Demin, A.A.; Pennicott, L.E.; Cihlarova, Z.; Caldecott, K.W. The Importance of Poly(ADP-Ribose) Polymerase as a Sensor of Unligated Okazaki Fragments during DNA Replication. Mol. Cell 2018, 71, 319-331.e3. [CrossRef] [PubMed]

194. Levin, D.S.; McKenna, A.E.; Motycka, T.A.; Matsumoto, Y.; Tomkinson, A.E. Interaction between PCNA and DNA ligase I is critical for joining of Okazaki fragments and long-patch base-excision repair. Curr. Biol. 2000, 10, 919-922. [CrossRef]

195. Iliakis, G.; Murmann, T.; Soni, A. Alternative end-joining repair pathways are the ultimate backup for abrogated classical nonhomologous end-joining and homologous recombination repair: Implications for the formation of chromosome translocations. Mutat. Res. Genet. Toxicol. Environ. Mutagen. 2015, 793, 166-175. [CrossRef] [PubMed]

196. Akbari, M.; Pena-Diaz, J.; Andersen, S.; Liabakk, N.B.; Otterlei, M.; Krokan, H.E. Extracts of proliferating and non-proliferating human cells display different base excision pathways and repair fidelity. DNA Repair 2009, 8, 834-843. [CrossRef]

197. Ferrari, G.; Rossi, R.; Arosio, D.; Vindigni, A.; Biamonti, G.; Montecucco, A. Cell cycle-dependent phosphorylation of human DNA ligase I at the cyclin-dependent kinase sites. J. Biol. Chem. 2003, 278, 37761-37767. [CrossRef]

198. Montecucco, A.; Biamonti, G.; Savini, E.; Focher, F.; Spadari, S.; Ciarrocchi, G. DNA ligase I gene expression during differentiation and cell proliferation. Nucleic Acids Res. 1992, 20, 6209-6214. [CrossRef]

199. Rossi, R.; Villa, A.; Negri, C.; Scovassi, I.; Ciarrocchi, G.; Biamonti, G.; Montecucco, A. The replication factory targeting sequence/PCNA-binding site is required in G(1) to control the phosphorylation status of DNA ligase, I. EMBO J. 1999, 18, 5745-5754. [CrossRef]

200. Karanjawala, Z.E.; Adachi, N.; Irvine, R.A.; Oh, E.K.; Shibata, D.; Schwarz, K.; Hsieh, C.L.; Lieber, M.R. The embryonic lethality in DNA ligase IV-deficient mice is rescued by deletion of $\mathrm{Ku}$ : Implications for unifying the heterogeneous phenotypes of NHEJ mutants. DNA Repair 2002, 1, 1017-1026. [CrossRef]

201. Gao, Y.; Ferguson, D.O.; Xie, W.; Manis, J.P.; Sekiguchi, J.; Frank, K.M.; Chaudhuri, J.; Horner, J.; DePinho, R.A.; Alt, F.W. Interplay of p53 and DNA-repair protein XRCC4 in tumorigenesis, genomic stability and development. Nature 2000, 404, 897-900. [CrossRef]

202. Gu, Y.; Sekiguchi, J.; Gao, Y.; Dikkes, P.; Frank, K.; Ferguson, D.; Hasty, P.; Chun, J.; Alt, F.W. Defective embryonic neurogenesis in Ku-deficient but not DNA-dependent protein kinase catalytic subunit-deficient mice. Proc. Natl. Acad. Sci. USA 2000, 97, 2668-2673. [CrossRef] [PubMed]

203. Yang, G.; Liu, C.; Chen, S.H.; Kassab, M.A.; Hoff, J.D.; Walter, N.G.; Yu, X. Super-resolution imaging identifies PARP1 and the Ku complex acting as DNA double-strand break sensors. Nucleic Acids Res. 2018, 46, 3446-3457. [CrossRef] [PubMed]

204. Ray Chaudhuri, A.; Nussenzweig, A. The multifaceted roles of PARP1 in DNA repair and chromatin remodelling. Nat. Rev. Mol. Cell Biol. 2017, 18, 610-621. [CrossRef] [PubMed]

205. Perina, D.; Mikoc, A.; Ahel, J.; Cetkovic, H.; Zaja, R.; Ahel, I. Distribution of protein poly(ADP-ribosyl)ation systems across all domains of life. DNA Repair 2014, 23, 4-16. [CrossRef]

206. Henrie, M.S.; Kurimasa, A.; Burma, S.; Menissier-de Murcia, J.; de Murcia, G.; Li, G.C.; Chen, D.J. Lethality in PARP-1/Ku80 double mutant mice reveals physiological synergy during early embryogenesis. DNA Repair 2003, 2, 151-158. [CrossRef]

207. Menisser-de Murcia, J.; Mark, M.; Wendling, O.; Wynshaw-Boris, A.; de Murcia, G. Early embryonic lethality in PARP-1 Atm double-mutant mice suggests a functional synergy in cell proliferation during development. Mol. Cell Biol. 2001, 21, 1828-1832. [CrossRef]

208. Menissier de Murcia, J.; Ricoul, M.; Tartier, L.; Niedergang, C.; Huber, A.; Dantzer, F.; Schreiber, V.; Ame, J.C.; Dierich, A.; LeMeur, M.; et al. Functional interaction between PARP-1 and PARP-2 in chromosome stability and embryonic development in mouse. EMBO J. 2003, 22, 2255-2263. [CrossRef]

209. Prasad, R.; Horton, J.K.; Wilson, S.H. Requirements for PARP-1 covalent crosslinking to DNA (PARP-1 DPC). DNA Repair 2020, 90, 102850. [CrossRef]

210. Williams, R.S.; Moncalian, G.; Williams, J.S.; Yamada, Y.; Limbo, O.; Shin, D.S.; Groocock, L.M.; Cahill, D.; Hitomi, C.; Guenther, G.; et al. Mre11 dimers coordinate DNA end bridging and nuclease processing in double-strand-break repair. Cell 2008, 135, 97-109. [CrossRef]

211. Andres, S.N.; Li, Z.M.; Erie, D.A.; Williams, R.S. Ctp1 protein-DNA filaments promote DNA bridging and DNA double-strand break repair. J. Biol. Chem. 2019, 294, 3312-3320. [CrossRef] 
212. Wilkinson, O.J.; Martin-Gonzalez, A.; Kang, H.; Northall, S.J.; Wigley, D.B.; Moreno-Herrero, F.; Dillingham, M.S. CtIP forms a tetrameric dumbbell-shaped particle which bridges complex DNA end structures for double-strand break repair. eLife 2019, 8, e42129. [CrossRef]

213. Oz, R.; Howard, S.M.; Sharma, R.; Tornkvist, H.; Ceppi, I.; Kk, S.; Kristiansson, E.; Cejka, P.; Westerlund, F. Phosphorylated CtIP bridges DNA to promote annealing of broken ends. Proc. Natl. Acad. Sci. USA 2020, 117, 21403-21412. [CrossRef]

214. Gamper, A.M.; Rofougaran, R.; Watkins, S.C.; Greenberger, J.S.; Beumer, J.H.; Bakkenist, C.J. ATR kinase activation in G1 phase facilitates the repair of ionizing radiation-induced DNA damage. Nucleic Acids Res. 2013, 41, 10334-10344. [CrossRef]

215. Shiotani, B.; Zou, L. Single-stranded DNA orchestrates an ATM-to-ATR switch at DNA breaks. Mol. Cell 2009, 33, 547-558. [CrossRef]

216. Bai, Y.; Wang, W.; Li, S.; Zhan, J.; Li, H.; Zhao, M.; Zhou, X.A.; Li, S.; Li, X.; Huo, Y.; et al. C1QBP Promotes Homologous Recombination by Stabilizing MRE11 and Controlling the Assembly and Activation of MRE11/RAD50/NBS1 Complex. Mol. Cell 2019, 75, 1299-1314.e6. [CrossRef]

217. Broderick, R.; Nieminuszczy, J.; Baddock, H.T.; Deshpande, R.; Gileadi, O.; Paull, T.T.; McHugh, P.J.; Niedzwiedz, W. EXD2 promotes homologous recombination by facilitating DNA end resection. Nat. Cell Biol. 2016, 18, 271-280. [CrossRef]

218. He, Y.J.; Meghani, K.; Caron, M.C.; Yang, C.; Ronato, D.A.; Bian, J.; Sharma, A.; Moore, J.; Niraj, J.; Detappe, A.; et al. DYNLL1 binds to MRE11 to limit DNA end resection in BRCA1-deficient cells. Nature 2018, 563, 522-526. [CrossRef] [PubMed]

219. Tkac, J.; Xu, G.; Adhikary, H.; Young, J.T.F.; Gallo, D.; Escribano-Diaz, C.; Krietsch, J.; Orthwein, A.; Munro, M.; Sol, W.; et al. HELB Is a Feedback Inhibitor of DNA End Resection. Mol. Cell 2016, 61, 405-418. [CrossRef] [PubMed]

220. West, K.L.; Kelliher, J.L.; Xu, Z.; An, L.; Reed, M.R.; Eoff, R.L.; Wang, J.; Huen, M.S.Y.; Leung, J.W.C. LC8/DYNLL1 is a 53BP1 effector and regulates checkpoint activation. Nucleic Acids Res. 2019, 47, 6236-6249. [CrossRef] [PubMed]

221. Zhao, F.; Kim, W.; Gao, H.; Liu, C.; Zhang, Y.; Chen, Y.; Deng, M.; Zhou, Q.; Huang, J.; Hu, Q.; et al. ASTE1 promotes shieldin-complex-mediated DNA repair by attenuating end resection. Nat. Cell Biol. 2021, 23, 894-904. [CrossRef]

222. Polo, L.M.; Xu, Y.; Hornyak, P.; Garces, F.; Zeng, Z.; Hailstone, R.; Matthews, S.J.; Caldecott, K.W.; Oliver, A.W.; Pearl, L.H. Efficient Single-Strand Break Repair Requires Binding to Both Poly(ADP-Ribose) and DNA by the Central BRCT Domain of XRCC1. Cell Rep. 2019, 26, 573-581.e5. [CrossRef]

223. Demin, A.A.; Hirota, K.; Tsuda, M.; Adamowicz, M.; Hailstone, R.; Brazina, J.; Gittens, W.; Kalasova, I.; Shao, Z.; Zha, S.; et al. XRCC1 prevents toxic PARP1 trapping during DNA base excision repair. Mol. Cell 2021, 81, 3018-3030.e5. [CrossRef]

224. Bienstock, R.J.; Beard, W.A.; Wilson, S.H. Phylogenetic analysis and evolutionary origins of DNA polymerase X-family members. DNA Repair 2014, 22, 77-88. [CrossRef]

225. Kim, K.; Pedersen, L.C.; Kirby, T.W.; DeRose, E.F.; London, R.E. Characterization of the APLF FHA-XRCC1 phosphopeptide interaction and its structural and functional implications. Nucleic Acids Res. 2017, 45, 12374-12387. [CrossRef] [PubMed]

226. Aceytuno, R.D.; Piett, C.G.; Havali-Shahriari, Z.; Edwards, R.A.; Rey, M.; Ye, R.; Javed, F.; Fang, S.; Mani, R.; Weinfeld, M.; et al. Structural and functional characterization of the PNKP-XRCC4-LigIV DNA repair complex. Nucleic Acids Res. 2017, 45, 6238-6251. [CrossRef] [PubMed]

227. Cherry, A.L.; Nott, T.J.; Kelly, G.; Rulten, S.L.; Caldecott, K.W.; Smerdon, S.J. Versatility in phospho-dependent molecular recognition of the XRCC1 and XRCC4 DNA-damage scaffolds by aprataxin-family FHA domains. DNA Repair 2015, 35, 116-125. [CrossRef] [PubMed]

228. Osheroff, W.P.; Jung, H.K.; Beard, W.A.; Wilson, S.H.; Kunkel, T.A. The fidelity of DNA polymerase beta during distributive and processive DNA synthesis. J. Biol. Chem. 1999, 274, 3642-3650. [CrossRef]

229. Chagovetz, A.M.; Sweasy, J.B.; Preston, B.D. Increased activity and fidelity of DNA polymerase beta on single-nucleotide gapped DNA. J. Biol. Chem. 1997, 272, 27501-27504. [CrossRef]

230. Huang, K.W.; Liu, T.C.; Liang, R.Y.; Chu, L.Y.; Cheng, H.L.; Chu, J.W.; Hsiao, Y.Y. Structural basis for overhang excision and terminal unwinding of DNA duplexes by TREX1. PLoS Biol. 2018, 16, e2005653. [CrossRef]

231. Miyazaki, T.; Kim, Y.S.; Yoon, J.; Wang, H.; Suzuki, T.; Morse 3rd, H.C. The $3^{\prime}-5^{\prime}$ DNA exonuclease TREX1 directly interacts with poly(ADP-ribose) polymerase-1 (PARP1) during the DNA damage response. J. Biol. Chem. 2014, 289, 32548-32558. [CrossRef]

232. Frank, K.M.; Sharpless, N.E.; Gao, Y.; Sekiguchi, J.M.; Ferguson, D.O.; Zhu, C.; Manis, J.P.; Horner, J.; DePinho, R.A.; Alt, F.W. DNA ligase IV deficiency in mice leads to defective neurogenesis and embryonic lethality via the p53 pathway. Mol. Cell 2000, 5, 993-1002. [CrossRef]

233. Kapitonov, V.V.; Jurka, J. RAG1 core and V(D)J recombination signal sequences were derived from Transib transposons. PLoS Biol. 2005, 3, e181. [CrossRef] [PubMed]

234. Martin, E.C.; Vicari, C.; Tsakou-Ngouafo, L.; Pontarotti, P.; Petrescu, A.J.; Schatz, D.G. Identification of RAG-like transposons in protostomes suggests their ancient bilaterian origin. Mob. DNA 2020, 11, 17. [CrossRef] [PubMed]

235. Carmona, L.M.; Fugmann, S.D.; Schatz, D.G. Collaboration of RAG2 with RAG1-like proteins during the evolution of V(D)J recombination. Genes Dev. 2016, 30, 909-917. [CrossRef] [PubMed]

236. Schatz, D.G.; Swanson, P.C. V(D)J recombination: Mechanisms of initiation. Ann. Rev. Genet. 2011, 45, 167-202. [CrossRef]

237. Lefranc, M.P. Nomenclature of the human immunoglobulin kappa (IGK) genes. Exp. Clin. Immunogenet. 2001, 18, 161-174. [CrossRef] [PubMed]

238. Lefranc, M.P. Nomenclature of the human immunoglobulin heavy (IGH) genes. Exp. Clin. Immunogenet. 2001, 18, 100-116. [CrossRef] [PubMed] 
239. Lin, S.G.; Ba, Z.; Alt, F.W.; Zhang, Y. RAG Chromatin Scanning During V(D)J Recombination and Chromatin Loop Extrusion are Related Processes. Adv. Immunol. 2018, 139, 93-135. [PubMed]

240. Zhang, Y.; Zhang, X.; Ba, Z.; Liang, Z.; Dring, E.W.; Hu, H.; Lou, J.; Kyritsis, N.; Zurita, J.; Shamim, M.S.; et al. The fundamental role of chromatin loop extrusion in physiological V(D)J recombination. Nature 2019, 573, 600-604. [CrossRef] [PubMed]

241. Schatz, D.G.; Ji, Y. Recombination centres and the orchestration of V(D)J recombination. Nat. Rev. Immunol. 2011, 11, $251-263$. [CrossRef]

242. Hu, J.; Zhang, Y.; Zhao, L.; Frock, R.L.; Du, Z.; Meyers, R.M.; Meng, F.L.; Schatz, D.G.; Alt, F.W. Chromosomal Loop Domains Direct the Recombination of Antigen Receptor Genes. Cell 2015, 163, 947-959. [CrossRef]

243. Zhao, L.; Frock, R.L.; Du, Z.; Hu, J.; Chen, L.; Krangel, M.S.; Alt, F.W. Orientation-specific RAG activity in chromosomal loop domains contributes to Tcrd V(D)J recombination during T cell development. J. Exp. Med. 2016, 213, 1921-1936. [CrossRef]

244. Ba, Z.; Lou, J.; Ye, A.Y.; Dai, H.Q.; Dring, E.W.; Lin, S.G.; Jain, S.; Kyritsis, N.; Kieffer-Kwon, K.R.; Casellas, R.; et al. CTCF orchestrates long-range cohesin-driven V(D)J recombinational scanning. Nature 2020, 586, 305-310. [CrossRef] [PubMed]

245. Dai, H.Q.; Hu, H.; Lou, J.; Ye, A.Y.; Ba, Z.; Zhang, X.; Zhang, Y.; Zhao, L.; Yoon, H.S.; Chapdelaine-Williams, A.M.; et al. Loop extrusion mediates physiological Igh locus contraction for RAG scanning. Nature 2021, 590, 338-343. [CrossRef] [PubMed]

246. Hill, L.; Ebert, A.; Jaritz, M.; Wutz, G.; Nagasaka, K.; Tagoh, H.; Kostanova-Poliakova, D.; Schindler, K.; Sun, Q.; Bonelt, P.; et al. Wapl repression by Pax 5 promotes V gene recombination by Igh loop extrusion. Nature 2020, 584, 142-147. [CrossRef] [PubMed]

247. Jain, S.; Ba, Z.; Zhang, Y.; Dai, H.Q.; Alt, F.W. CTCF-Binding Elements Mediate Accessibility of RAG Substrates During Chromatin Scanning. Cell 2018, 174, 102-116.e14. [CrossRef] [PubMed]

248. Lovely, G.A.; Braikia, F.-Z.; Singh, A.; Schatz, D.G.; Murre, C.; Liu, Z.; Sen, R. Direct observation of RAG recombinase recruitment to chromatin and the IgH locus in live pro-B cells. bioRxiv 2020. [CrossRef]

249. Helmink, B.A.; Sleckman, B.P. The response to and repair of RAG-mediated DNA double-strand breaks. Ann. Rev. Immunol. 2012, 30, 175-202. [CrossRef]

250. Deriano, L.; Stracker, T.H.; Baker, A.; Petrini, J.H.; Roth, D.B. Roles for NBS1 in alternative nonhomologous end-joining of V(D)J recombination intermediates. Mol. Cell 2009, 34, 13-25. [CrossRef]

251. Chaumeil, J.; Micsinai, M.; Ntziachristos, P.; Roth, D.B.; Aifantis, I.; Kluger, Y.; Deriano, L.; Skok, J.A. The RAG2 C-terminus and ATM protect genome integrity by controlling antigen receptor gene cleavage. Nat. Commun. 2013, 4, 2231. [CrossRef]

252. Corneo, B.; Wendland, R.L.; Deriano, L.; Cui, X.; Klein, I.A.; Wong, S.Y.; Arnal, S.; Holub, A.J.; Weller, G.R.; Pancake, B.A.; et al. Rag mutations reveal robust alternative end joining. Nature 2007, 449, 483-486. [CrossRef] [PubMed]

253. Deriano, L.; Chaumeil, J.; Coussens, M.; Multani, A.; Chou, Y.; Alekseyenko, A.V.; Chang, S.; Skok, J.A.; Roth, D.B. The RAG2 C terminus suppresses genomic instability and lymphomagenesis. Nature 2011, 471, 119-123. [CrossRef]

254. Gigi, V.; Lewis, S.; Shestova, O.; Mijuskovic, M.; Deriano, L.; Meng, W.; Luning Prak, E.T.; Roth, D.B. RAG2 mutants alter DSB repair pathway choice in vivo and illuminate the nature of 'alternative NHEJ'. Nucleic Acids Res. 2014, 42, 6352-6364. [CrossRef] [PubMed]

255. Jiang, H.; Chang, F.C.; Ross, A.E.; Lee, J.; Nakayama, K.; Nakayama, K.; Desiderio, S. Ubiquitylation of RAG-2 by Skp2-SCF links destruction of the V(D)J recombinase to the cell cycle. Mol. Cell 2005, 18, 699-709. [CrossRef]

256. Lee, J.; Desiderio, S. Cyclin A/CDK2 regulates V(D)J recombination by coordinating RAG-2 accumulation and DNA repair. Immunity 1999, 11, 771-781. [CrossRef]

257. Li, Z.; Dordai, D.I.; Lee, J.; Desiderio, S. A conserved degradation signal regulates RAG-2 accumulation during cell division and links V(D)J recombination to the cell cycle. Immunity 1996, 5, 575-589. [CrossRef]

258. Coussens, M.A.; Wendland, R.L.; Deriano, L.; Lindsay, C.R.; Arnal, S.M.; Roth, D.B. RAG2's acidic hinge restricts repair-pathway choice and promotes genomic stability. Cell Rep. 2013, 4, 870-878. [CrossRef]

259. Lu, C.; Ward, A.; Bettridge, J.; Liu, Y.; Desiderio, S. An autoregulatory mechanism imposes allosteric control on the V(D)J recombinase by histone H3 methylation. Cell Rep. 2015, 10, 29-38. [CrossRef]

260. Ward, A.; Kumari, G.; Sen, R.; Desiderio, S. The RAG-2 Inhibitory Domain Gates Accessibility of the V(D)J Recombinase to Chromatin. Mol. Cell Biol. 2018, 38, e00159-18. [CrossRef]

261. Ji, Y.; Resch, W.; Corbett, E.; Yamane, A.; Casellas, R.; Schatz, D.G. The in vivo pattern of binding of RAG1 and RAG2 to antigen receptor loci. Cell 2010, 141, 419-431. [CrossRef]

262. Teng, G.; Maman, Y.; Resch, W.; Kim, M.; Yamane, A.; Qian, J.; Kieffer-Kwon, K.R.; Mandal, M.; Ji, Y.; Meffre, E.; et al. RAG Represents a Widespread Threat to the Lymphocyte Genome. Cell 2015, 162, 751-765. [CrossRef]

263. Akamatsu, Y.; Monroe, R.; Dudley, D.D.; Elkin, S.K.; Gartner, F.; Talukder, S.R.; Takahama, Y.; Alt, F.W.; Bassing, C.H.; Oettinger, M.A. Deletion of the RAG2 C terminus leads to impaired lymphoid development in mice. Proc. Natl. Acad. Sci. USA 2003, 100, $1209-1214$. [CrossRef]

264. Fattah, F.; Lee, E.H.; Weisensel, N.; Wang, Y.; Lichter, N.; Hendrickson, E.A. Ku regulates the non-homologous end joining pathway choice of DNA double-strand break repair in human somatic cells. PLoS Genet. 2010, 6, e1000855. [CrossRef] [PubMed]

265. Fattah, F.J.; Kweon, J.; Wang, Y.; Lee, E.H.; Kan, Y.; Lichter, N.; Weisensel, N.; Hendrickson, E.A. A role for XLF in DNA repair and recombination in human somatic cells. DNA Repair 2014, 15, 39-53. [CrossRef] [PubMed]

266. Finnie, N.J.; Gottlieb, T.M.; Blunt, T.; Jeggo, P.A.; Jackson, S.P. DNA-dependent protein kinase activity is absent in xrs-6 cells: Implications for site-specific recombination and DNA double-strand break repair. Proc. Natl. Acad. Sci. USA 1995, 92, 320-324. [CrossRef] [PubMed] 
267. Ghezraoui, H.; Piganeau, M.; Renouf, B.; Renaud, J.B.; Sallmyr, A.; Ruis, B.; Oh, S.; Tomkinson, A.E.; Hendrickson, E.A.; Giovannangeli, C.; et al. Chromosomal translocations in human cells are generated by canonical nonhomologous end-joining. Mol. Cell 2014, 55, 829-842. [CrossRef]

268. Li, G.; Nelsen, C.; Hendrickson, E.A. Ku86 is essential in human somatic cells. Proc. Natl. Acad. Sci. USA 2002, 99, 832-837. [CrossRef]

269. Ruis, B.; Molan, A.; Takasugi, T.; Hendrickson, E.A. Absence of XRCC4 and its paralogs in human cells reveal differences in outcomes for DNA repair and V(D)J recombination. DNA Repair 2020, 85, 102738. [CrossRef]

270. Wang, Y.; Ghosh, G.; Hendrickson, E.A. Ku86 represses lethal telomere deletion events in human somatic cells. Proc. Natl. Acad. Sci. USA 2009, 106, 12430-12435. [CrossRef] 